\title{
Gantenerumab: A Novel Human Anti-A $\beta$ Antibody Demonstrates Sustained Cerebral Amyloid- $\beta$ Binding and Elicits Cell-Mediated Removal of Human
} Amyloid- $\beta$

\author{
Bernd Bohrmann ${ }^{\mathrm{a}, *}$, Karlheinz Baumann ${ }^{\mathrm{a}}$, Jörg Benz ${ }^{\mathrm{a}}$, Francoise Gerber ${ }^{\mathrm{a}}$, Walter Huber ${ }^{\mathrm{a}}$, \\ Frédéric Knoflach $^{\mathrm{a}}$, Jürg Messer ${ }^{\mathrm{a}}$, Krisztina Oroszlan ${ }^{\mathrm{a}}$, Robert Rauchenberger ${ }^{\mathrm{b}}$, Wolfgang F. Richter ${ }^{\mathrm{a}}$, \\ Christine Rothe $^{\mathrm{b}}$, Margit Urban ${ }^{\mathrm{b}}$, Michael Bardroff ${ }^{\mathrm{b}}$, Michael Winter ${ }^{\mathrm{a}}$, Christer Nordstedt ${ }^{\mathrm{a}}$ \\ and Hansruedi Loetscher ${ }^{\mathrm{a}}$ \\ ${ }^{a}$ F. Hoffmann-La Roche Ltd., pRED, Basel, Switzerland \\ ${ }^{\mathrm{b}}$ MorphoSys AG, Martinsried, Germany
}

Handling Associate Editor: Alex Roher

Accepted 10 August 2011

\begin{abstract}
The amyloid- $\beta$ lowering capacity of anti-A $\beta$ antibodies has been demonstrated in transgenic models of Alzheimer's disease (AD) and in AD patients. While the mechanism of immunotherapeutic amyloid- $\beta$ removal is controversial, antibodymediated sequestration of peripheral $A \beta$ versus microglial phagocytic activity and disassembly of cerebral amyloid (or a combination thereof) has been proposed. For successful $A \beta$ immunotherapy, we hypothesized that high affinity antibody binding to amyloid- $\beta$ plaques and recruitment of brain effector cells is required for most efficient amyloid clearance. Here we report the generation of a novel fully human anti-A $\beta$ antibody, gantenerumab, optimized in vitro for binding with sub-nanomolar affinity to a conformational epitope expressed on amyloid- $\beta$ fibrils using $\mathrm{HuCAL}^{\circledR}$ phage display technologies. In peptide maps, both $\mathrm{N}$-terminal and central portions of $\mathrm{A} \beta$ were recognized by gantenerumab. Remarkably, a novel orientation of $\mathrm{N}$-terminal $\mathrm{A} \beta$ bound to the complementarity determining regions was identified by $\mathrm{x}$-ray analysis of a gantenerumab Fab-A $\beta_{1-11}$ complex. In functional assays gantenerumab induced cellular phagocytosis of human amyloid- $\beta$ deposits in AD brain slices when co-cultured with primary human macrophages and neutralized oligomeric $A \beta_{42}$-mediated inhibitory effects on long-term potentiation in rat brain. In APP751 $1_{\text {swedish }} \mathrm{XPS} 2_{\mathrm{N} 141 \mathrm{I}}$ transgenic mice, gantenerumab showed sustained binding to cerebral amyloid- $\beta$ and, upon chronic treatment, significantly reduced small amyloid- $\beta$ plaques by recruiting microglia and prevented new plaque formation. Unlike other $A \beta$ antibodies, gantenerumab did not alter plasma $A \beta$ suggesting undisturbed systemic clearance of soluble $A \beta$. These studies demonstrated that gantenerumab preferentially interacts with aggregated $A \beta$ in the brain and lowers amyloid- $\beta$ by eliciting effector cell-mediated clearance.
\end{abstract}

Keywords: Alzheimer's disease, $\mathrm{A} \beta$, amyloid- $\beta$, antibody, $\mathrm{HuCAL}^{\circledR}$, immunotherapy

\footnotetext{
${ }^{*}$ Correspondence to: Bernd Bohrmann, F. Hoffmann-La Roche Ltd., pRED, Basel, Switzerland. E-mail: bernd.bohrmann@ roche. com.
} 


\section{INTRODUCTION}

Alzheimer's disease (AD) is the world's leading cause of dementia and the most prevalent neurodegenerative disease. The majority, an estimated $50-75 \%$ of all dementia cases, are caused by AD. The disease is characterized by a progressive loss of cognitive function and because of the increasing prevalence, $\mathrm{AD}$ is expected to become a major challenge in increasingly aging societies. Currently available medications are based on symptomatic intervention but do not cure AD. The amyloid- $\beta(A \beta)$ hypothesis suggests an agedependent accumulation of the $A \beta$ peptide as a critical step in the cascade of pathological events that cause deficits in synaptic functionality and lead to severe neurodegeneration in $\mathrm{AD}$ [1]. Thus, approaches to decrease accumulation of $A \beta$ are actively explored as a therapeutic modality for treatment of AD.

Initial studies using active immunization with fibrillar $A \beta$ in transgenic mouse models of AD demonstrated reduction of amyloid- $\beta$ plaque pathology and ability to restore memory deficits [2, 3]. However, subsequent clinical evaluation of active immunization with fibrillar $A \beta_{1-42}(\mathrm{AN}-1792)$ revealed unwanted inflammatory reactions attributable to infiltrating $\mathrm{T}$ cells caused by the immunogen in combination with detergent and the used adjuvant QS-21 in 6\% of patients suggestive for a deleterious Th1 response [4]. Several patients with anti-A $\beta$ antibodies showed signs of plaque clearance at autopsy $[5,6]$ but subsequent clinical studies failed to show unequivocal improvement in patients with substantial levels of anti-A $\beta$ antibodies $[7,8,9]$. As an alternative to active immunization, passive immunization demonstrated activity in transgenic animal models, e.g., $[10,11]$, through mechanisms that appear to include: (i) prevention of $A \beta$ fibril formation [12], (ii) inhibition of neuro/synapto-toxic oligomers of $A \beta$ [13], (iii) enhancement of cerebral $A \beta$ efflux by a postulated equilibrium shift [11] or by receptor-mediated efflux of antibody-bound $A \beta$ [14], and (iv) eliciting Fc receptor-mediated phagocytosis of antibody-bound $\mathrm{A} \beta[10]$.

An increasing number of anti-A $\beta$ antibodies that were proposed to act by different, although not mutually exclusive mechanism(s), are currently explored as potential therapeutics for AD [15]. The molecular properties that determine successful therapeutic application of anti-A $\beta$ antibodies are under debate and controlled clinical studies are needed to identify the major mechanism(s) of successful amyloid removal by antibodies. We identified specific anti-A $\beta$ antibodies by screening a human phage display library
$\mathrm{HuCAL}^{\circledR}{ }_{-}$-Fab1 [16] and optimized selected candidates for specific and high avidity binding to $A \beta$ plaques, both in vitro and in vivo. The finally selected antibody, gantenerumab, showed a unique molecular binding mode to the $\mathrm{N}$-terminal portion of $\mathrm{A} \beta$ together with binding to central amino acids of the $A \beta$ peptide, which is markedly different from other anti-A $\beta$ antibodies previously described $[17,18,19]$. The amyloid- $\beta$ lowering capacity was confirmed in an ex vivo phagocytosis assay using human effector cells and in vivo in PS2APP double transgenic mice. This is the first report of a fully human anti-A $\beta$ monoclonal antibody characterized in preclinical models of $\mathrm{AD}$ focused on $\mathrm{A} \beta$ clearance mechanism(s). The activity of gantenerumab in these models indicates its potential for efficacy in humans.

\section{MATERIALS AND METHODS}

\section{Monoclonal anti-A $\beta$ antibodies}

Gantenerumab was derived from a parental clone obtained from the MorphoSys HuCAL ${ }^{\circledR}$-Fab1 phage display library [16] and engineered by in vitro maturation using CDR cassette exchanges [20]. Gantenerumab antibody material was obtained from a $\mathrm{CHO}$ production clone. Murine anti-A $\beta$ antibodies BAP2 (specific for the $\mathrm{A} \beta$ peptide epitope comprising amino acids 2-8 [21]), BAP41 (specific for the A $\beta$ peptide epitope comprising amino acids 5-10), and BAP44 (specific for the $\mathrm{A} \beta$ peptide epitope comprising amino acids 20-21) were generated and selected by using standard hybridoma technologies [22].

\section{Affinity measurements by surface plasmon spectroscopy}

Affinity was measured online with surface plasmon resonance using a Biacore 3000 instrument. Purified human anti-A $\beta$ antibody preparations with $>99 \%$ monomer verified by size exclusion chromatography were analyzed.

Synthetic $A \beta_{40}$ peptides were obtained from Bachem (Bachem, Inc., Switzerland). Solubilization and aggregate formation were adapted from published procedures [23]. Binding to monomeric $A \beta$ peptides was studied with samples resolubilized in 1,1,1,3,3,3-hexafluoro-2-propanol (HFIP, Fluka $52512)$ at $1 \mathrm{mg} / \mathrm{mL}$. A $\beta$ monomers were immobilized at 5 response units (RU; equivalent to $\sim 5 \mathrm{pg} / \mathrm{mm}^{2}$ ) on a Streptavidin sensor chip (SA BR-1000-32 from GE Healthceare). 
A $\beta$ oligomers were prepared by HFIP pre-treated synthetic $\mathrm{A} \beta_{40}$ and solubilized at $50 \mu \mathrm{M}$ in $10 \mathrm{mM}$ Tris, $\mathrm{pH}$ 7. Care was taken to avoid extensive vortexing and to use pre-cooled buffer. Oligomer preparations were analyzed by analytical ultracentrifugation and revealed a mixture consisting predominantly of trimers, tetramers, and higher oligomeric states with residual minor fraction of monomers. This preparation of oligomers was stable for at least 2 weeks if stored at $4{ }^{\circ} \mathrm{C}$ (data not shown). A $\beta$ fibrils were obtained from synthetic $A \beta_{40}$ peptides incubated at a concentration of $200 \mu \mathrm{g} / \mathrm{ml}$ in $10 \mathrm{mM}$ sodium-acetate buffer ( $\mathrm{pH} 4.0$ ) for three days at $37^{\circ} \mathrm{C}$. Electron microscopic analysis confirmed either spheroidal (i.e., oligomeric) or fibrillar ultrastructure for the oligomers and fibril preparations, respectively (data not shown). A $\beta_{40}$ fibrils and oligomers generated in vitro were coupled to a CM5 chip at $200 \mathrm{RU}$ as described in instruction manual of the manufacturer. The equilibrium dissociation constant $\left(K_{D}\right)$ values were obtained from equilibrium responses with a Scatchard type analysis by retrieving values for divalent binding from the maximum slope and values for monomeric binding from the minimum slope. The $\mathrm{K}_{\mathrm{D}}$ values and the kinetic rate constants ka and kd were retrieved by a kinetic fit based on a monovalent binding model and plotting the equilibrium sensor responses versus the respective concentration and fitting the resulting curve with the mathematical equation of a Langmuir isotherm.

\section{Epitope mapping}

The amino acid sequence encompassing $A \beta_{42}$ ISEVKM ${ }^{1}$ DAEF RHDSGYEVHH QKLVFFAEDV GSNKGAIIGL MVGGVVI ${ }^{42}$ ATV IV was divided into 43 overlapping decapeptides with a frameshift of 1 amino acid. 43 peptide sequences were used starting with ISEVKMDAEF and ending with GGVVIATVIV. The 43 decapeptides were synthesized with N-terminal acetylation and C-terminal covalent attachment to a cellulose sheet ("pepspot") by a commercial supplier (Jerini BioTools). The cellulose sheet was incubated for $2 \mathrm{~h}$ on a rocking platform with gantenerumab at $1 \mu \mathrm{g} / \mathrm{ml}$ in blocking buffer $(50 \mathrm{mM}$ Tris $\cdot \mathrm{HCl}, 140 \mathrm{mM}$ $\mathrm{NaCl}, 5 \mathrm{mM} \mathrm{Na} 2$ EDTA, $0.05 \%$ NP40 (Fluka), 0.25\% gelatine (Sigma), $1 \%$ bovine serum albumin fraction $\mathrm{V}$ (Sigma), pH 7.4). The sheet was transferred to a semidry blotting stack with the peptide side facing a PVDF membrane (Biorad) of equal size. After blotting, reactive peptides were detected by goat anti-human IgG $(\mathrm{H}+\mathrm{L})$ labeled with fluorochrome IRdye800 (Rockland code\# 609-132-123) added at $1: 10,000$ dilution in Odyssey blocking buffer and further diluted 1:1 with PBS, $0.05 \%$ Tween 20 and scanned at $800 \mathrm{~nm}$ by a fluorescence scanner (Odyssey).

\section{X-ray crystallography}

Fab fragments were purified after papain digestion of gantenerumab and the Fc and Fab fragments were separated on a Resource $\mathrm{S}$ column by ion exchange chromatography. Fab fragment containing fractions were concentrated to $15 \mathrm{mg} / \mathrm{mL}$ and crystallized by vapor diffusion in sitting drops. Gantenerumab Fab were crystallized out of 25\% PEG 3350, $0.1 \mathrm{M}$ Bis-Tris 6.5, and 0.2 M ammonium sulfate. The Fab/A $\beta$ complex was obtained by soaking the crystals with a $10 \mathrm{mM}$ peptide solution of $A \beta_{1-11}$ or $A \beta_{3-11}$ for $24 \mathrm{~h}$. For data collection, crystals were cryoprotected by addition of $15 \%$ glycerol and flash frozen in liquid nitrogen. Data have been collected to a resolution of $1.8 \AA$ at a wavelength of $0.9999 \AA$ at the beamline X10SA at the Swiss Light Source (Villigen, Switzerland). Crystals belong to the monoclinic space group $\mathrm{P} 21$ with cell axes of $a=71.14 \AA, b=66.24 \AA, c=105.16 \AA, \beta=99.1^{\circ}$. Programs [24] were used to process and subsequently refine the data by rigid body and positional refinement against an existing in house apo structure of the gantenerumab Fab fragment. Difference electron density was used to place the peptide by real space refinement. Manual rebuilding of protein and peptide was done with COOT [25]. In the final structure, the heavy chains excluding part of CDR H3, the complete light chains and the bound $A \beta$ peptides (residues 1-11) were traced. Two sulfate ions, 731 water molecules and, at residue Asn52 of the heavy chains, one NAG sugar unit was modeled into the electron density.

\section{Transgenic mice}

Male and female APP751 $1_{\text {swedish }} \times \mathrm{PS} 2_{\mathrm{N} 141 \mathrm{I}}$ (PS2APP) [26] in-house strain B16.152 H on a homozygous C57BL/6 background were used at plaque-bearing ages between 4 and 10 months. Mice were intravenously (iv) injected with different doses of anti-A $\beta$ antibodies and $20 \mathrm{mM}$ histidine buffer with $140 \mathrm{mM} \mathrm{NaCl}$ and $0.01 \%$ Tween-20, pH 5.5 as vehicle control. For plaque binding analysis a single injection of gantenerumab was administered to approximately 7-month-old PS2APP mice and analyzed after 3 days or up to 9 weeks after gantenerumab administration. Antibody-injected mice were anaesthetized $(\sim 2 \mathrm{~min}$ in $5 \% \mathrm{v} / \mathrm{v}$ Forene ${ }^{\mathrm{TM}}$ ) and animals perfused with $20 \mathrm{~mL}$ PBS $(\sim 10 \mathrm{~mL} / \mathrm{min})$. Brains were removed 
and immediately frozen on powdered dry ice. All procedures were conducted in strict adherence to the Swiss federal regulations on animal protection, to the rules of the Association for Assessment and Accreditation of Laboratory Animal Care and with the explicit approval of the local veterinary authority.

For chronic treatment, gantenerumab was administered to 5-6 month old male PS2A $\beta$ PP mice by weekly iv bolus injections, $20 \mathrm{mg} / \mathrm{kg}$ body weight, via the tail vein for 5 months. The baseline level of $A \beta$ plaque load at the beginning of the study was determined in untreated PS2APP mice. To prevent an antibody response to gantenerumab in chronically treated transgenic mice such mice received a non-lytic anti-CD4 monoclonal antibody acting on regulatory T cells [27]. A single iv injection of $0.5 \mathrm{mg}$ of an anti-CD4 antibody (ATCC hybridome clone GK 1.5) was given to all mice, including the wildtype C57BL/6 mice and PS2APP vehicle treated mice, to transiently deplete peripheral CD4+ T-helper cells one day before the start of gantenerumab administration. Presence of anti-drug antibodies against gantenerumab was monitored by surface plasmon resonance spectroscopy at monthly intervals by retroorbital blood sampling during the course of the study. Behavioral testing of locomotor activity and memory in the Morris water maze was done as described earlier [26]. After 5 month treatment, all groups learned to find the visible platform (data not shown). Unexpectedly, all groups had a spatial learning impairment, as shown by the lack of preference for the platform quadrant during the probe trial (data not shown). It is important to note that also in the vehicletreated wildtype group animals did not learn the task. All animal experimentation was compliant with the guide of the institution in which the experiments were done and protocol approval by the Institutional Animal Care and Use Committee.

\section{Quantification of A $\beta$ peptides in plasma}

Four month old PS2APP mice received a single iv injection of anti-A $\beta$ antibodies gantenerumab, BAP41, and BAP44 at a dose of $20 \mathrm{mg} / \mathrm{kg}$ body weight and plasma concentrations of $A \beta_{40}$ and $A \beta_{42}$ peptides were determined after 3 days using Liquid Phase Electrochemiluminescence (LPECL) assay technology. The immunoassay was done according to manufacturer's instructions (Meso Scale Discovery, Gaithersburg, Maryland). Streptavidin pre-coated 96well plates were incubated with blocking buffer $(5 \%$ BSA, $20 \mathrm{mM}$ Na-phosphate, $120 \mathrm{mM} \mathrm{NaCl}, 0.05 \%$ CHAPS, $\mathrm{pH}$ 7.4) for $2 \mathrm{~h}$ at room temperature. After discarding blocking solution, plates were filled with $50 \mu \mathrm{L} /$ well of capture antibody 4G8-bio (Signet) diluted at $1 \mu \mathrm{g} / \mathrm{ml}$ in assay buffer $(20 \mathrm{mM} \mathrm{Na}$ phosphate, $120 \mathrm{mM} \mathrm{NaCl}, 0.05 \%$ CHAPS, $0.5 \%$ BSA, $0.4 \%$ milk powder, $2 \mathrm{mM}$ EDTA, $0.05 \% \mathrm{NaN} 3, \mathrm{pH}$ $7.4)$ and incubated for $2 \mathrm{~h}$ at room temperature. Plates were then washed three times with wash buffer $(20 \mathrm{mM}$ Na-phosphate, $120 \mathrm{mM} \mathrm{NaCl}, 0.05 \%$ CHAPS, pH 7.4) followed by addition of $50 \mu \mathrm{L} /$ well of either $A \beta$ peptide standards, blanks or samples diluted $1: 3$ in assay buffer and incubated overnight at $4^{\circ} \mathrm{C}$. After washing, either TAG-labeled antibody BAP24 (for A $\beta_{40}$ ) or TAG-labeled antibody BAP15 (for $\mathrm{A} \beta_{42}$ [28]) was added to the plates and incubated for $3 \mathrm{~h}$ at room temperature. After washing, plates were filled with Mesoscale Read Buffer and read in a Sector Imager reader 6000 according to manufacturer's instructions. Data were statistically analyzed by one-way ANOVA with Tukey's multiple comparison test.

\section{Quantification of A $\beta$ peptides}

$A \beta_{40}$ and $A \beta_{42}$ were extracted from PS2APP mice treated over 5 months with gantenerumab using a two-step protocol. Cerebral hemispheres were homogenized in $1 \mathrm{~mL}$ of DEA buffer $(2 \%$ diethanolamine, $50 \mathrm{mM} \mathrm{NaCl}$ ) using the MagNAlyser (F. HoffmannLa Roche). The supernatants containing DEA soluble $\mathrm{A} \beta$ were collected after centrifugation and neutralized to $\mathrm{pH} 8$ with $1 \mathrm{M}$ Tris-HCl. To extract insoluble $\mathrm{A} \beta$, pellets were resuspended in $1 \mathrm{~mL} 9 \mathrm{M}$ urea, incubated overnight at $4^{\circ} \mathrm{C}$ and supernatants collected after centrifugation. Both supernatants (collected after either DEA or urea extraction) were tested in ELISA. The antibody combination used for the detection of $\mathrm{A} \beta$ peptides in brain extracts comprised biotinylated monoclonal antibody 4G8 (Senetek) for the capture and horseradish peroxidase (HRP) conjugated Roche in-house monoclonal antibodies HRP-BAP24 and HRP-BAP15 for the detection of $A \beta_{40}$ and $A \beta_{42}$, respectively. Control experiments addressing the influence of human anti-A $\beta$ antibody were done by spiking brain homogenate from the vehicle treated group with gantenerumab up to $1 \mu \mathrm{g} / \mathrm{mL}$. No interference of gantenerumab in the $A \beta$ measurements was observed. The ELISA was performed as previously described [26].

\section{Long-term potentiation in vivo}

Sprague Dawley rats (300-350 g) were anesthetized with an i.p., injection of urethane (ethyl carbamate, $1.5 \mathrm{~g} / \mathrm{kg}$ ) and supplementary injections were given 
when necessary. Body temperature was maintained at $36-37^{\circ} \mathrm{C}$ and constantly monitored. Field excitatory postsynaptic potentials (fEPSPs) were recorded in the stratum radiatum of the hippocampus by stimulating the Schaffer collateral commissural pathway. For this, a recording electrode (TM33B10KT, WPI, Sarasota, FL) was positioned $3.4 \mathrm{~mm}$ posterior and $2.5 \mathrm{~mm}$ lateral to the midline and a stimulation electrode (PTN3CC02INS, WPI) $4.2 \mathrm{~mm}$ posterior and $3.8 \mathrm{~mm}$ lateral to the midline. For intracerebroventricular (icv) injection, a cannula (Introcan 18 G, B. Braun Melsungen AG) was placed in the lateral ventricle, $0.8 \mathrm{~mm}$ posterior, $1.5 \mathrm{~mm}$ lateral to the midline and 3.7 ventral to bregma. Test stimuli lasting for $100 \mu$ s were delivered every $30 \mathrm{~s}$ at a current intensity evoking $50 \%$ of maximum fEPSP. Long-term potentiation (LTP) was induced by a high frequency stimulation (HFS) protocol consisting of 10 trains of 20 stimuli $(200 \mu \mathrm{s})$ at $200 \mathrm{~Hz}, 2 \mathrm{~s}$ intertrain interval at an intensity evoking a $75 \%$ maximum fEPSPs. The fEPSP slopes $(30-70 \%)$ were normalized to the 10-min period before icv injection and represented as mean $\pm \mathrm{SEM}$. $\mathrm{A} \beta_{42}$ (stored at $-80^{\circ} \mathrm{C}$ ) was solubilized to $50 \mu \mathrm{M}$ in $10 \mathrm{mM}$ Tris, $\mathrm{pH}$ 7.4 and incubated overnight at $4{ }^{\circ} \mathrm{C}$ (oligomer forming conditions). Immediately before use, the $A \beta_{42}$ solution was diluted in Tris to a concentration of $100 \mathrm{nM}$. Vehicle or $A \beta_{42}$ solutions $(5 \mu \mathrm{L})$ with and without gantenerumab or the $\mathrm{N}$-terminal specific anti-A $\beta$ antibody 6E10 (Senetek) were injected over a 5-min period $1 \mathrm{~h}$ before high frequency stimulation. LTP was induced with $A \beta_{42}$ in absence and presence of gantenerumab. Statistical significance was assessed using one way ANOVA with Dunnett's post-hoc analysis for comparison to vehicle and Tukey's post-hoc analysis for pair-wise comparisons $(p<0.05$ was considered significant).

\section{Immunohistochemistry}

Cryosections of mouse brains and postmortem human frontal cortices from AD cases at Braak stage VI [29] were prepared at 10 and $20 \mu \mathrm{m}$ nominal thickness, treated with ice-cold acetone and washed in PBS. Blocking of unspecific binding sites was done with $2 \%$ BSA or sequential incubation in Ultra V block (LabVision) for $15 \mathrm{~min}$ followed by a PBS wash and incubation in power block solution (BioGenex) with $10 \%$ normal sheep serum for $20 \mathrm{~min}$. Gantenerumab was detected by an affinity-purified goat anti-human $\operatorname{IgG}(\mathrm{H}+\mathrm{L})$ conjugated to Alexa555 or Cy3 (\#A-21433, lot 54699A, Molecular Probes, or \#109-165-003, lot 49353, Jackson Immuno Research) at a concentration of $15 \mu \mathrm{g} / \mathrm{mL}$ in $2 \%$ normal goat serum in PBS, $\mathrm{pH} 7.4$ for $1 \mathrm{~h}$ at room temperature. Counterstaining for $A \beta$ plaques was done by incubation with BAP2, a mouse monoclonal antibody against $A \beta$ conjugated to Alexa488 at a concentration of $0.5 \mu \mathrm{g} / \mathrm{mL}$ for $1 \mathrm{~h}$ at room temperature. For deconvolution image processing, $40 \mu \mathrm{m}$ thick slices were used after postfixation with $2 \%$ formaldehyde followed by double staining as described above. Triple staining against microglia was done after perfusion fixation with $4 \%$ formaldehyde and sequential of $40 \mu \mathrm{m}$ thick floating sections with a rat anti-mouse antibody that reacts against I-A/I-E MHC class II alloantigens present on activated microglia (clone 2G9, BD Biosciences Pharmingen, San Jose, CA) at $10 \mu \mathrm{g} / \mathrm{mL}$ incubated overnight and detected by goat anti-rat IgG conjugated to Alexa 488 (Molecular Probes) followed by secondary antibodies against gantenerumab and BAP2 conjugated to Alexa647 at concentrations as described above. AD cases included in this study were obtained from the departments of neuropathology of the Sun Health Research Institute (University of Arizona) with informed consent obtained for the use of human brain tissue and for access to medical records for research purposes. Tissue was obtained and used in a manner compliant with the ethical standards of the Committee on Human Experimentation of the institution in which the experiments were done and in accord with the Helsinki Declaration of 1975 and was approved by the local Institutional Review Board.

\section{Microscopy and image processing}

Confocal images were recorded using a HCX PL APO $40 \times$, NA 1.25 oil immersion or HCX PL APO $63 \times$, NA 1.4 oil immersion objectives on a Leica SP2 confocal microscope and processed with IMARIS software (Bitplane, Switzerland). Relative fluorescence intensity of plaque bound gantenerumab was determined from 5 images per animal and three animals per dose group using the IMARIS MeasurementPro module. Images shown represent maximum intensity projections of the z-series images. Deconvolution was done with HUYGENS software (Scientific Volume Imaging, Netherland) and colocalization was analyzed using the IMARIS Coloc module. Plaque load in the phagocytosis assay was determined by the average surface area obtained from 5 images in grey matter regions and calculated using the IMARIS SurpassPro software module. Surface visualization of triple stainings was also created with IMARIS SurpassPro. 
Quantification of plaque number in PS2APP mice was obtained from five sagittal sections per mouse within the hippocampal formation using every 10th section cut at $10 \mu \mathrm{m}$ nominal thickness. After staining of sections with gantenerumab at $5 \mu \mathrm{g} / \mathrm{mL}$ for $1 \mathrm{~h}$ at room temperature and detection by affinity-purified goat anti-human $\operatorname{IgG}(\mathrm{H}+\mathrm{L})$ conjugated to Alexa555 at $15 \mu \mathrm{g} / \mathrm{mL}$ for $1 \mathrm{~h}$ at room temperature, images were scanned with a GenePix Personal 4100A microarray scanner (Axon Instruments, now Molecular Devices, Sunnyvale CA, USA) and analyzed with MCID M7 Elite software (Interfocus Ltd., Haverhill, England). Calculations were made with common spreadsheet software (Microsoft Excel, Redmond, WA, USA). Statistical evaluation was done using a two-tailed, heteroscedastic $t$-test. Immunogold labeling and electron microscopy was done with gantenerumab at $10 \mu \mathrm{g} / \mathrm{mL}$ and detected with goat anti-human detection antibody coupled to 10 nanometer colloidal gold. Immunogold stainings were done with synthetic $A \beta_{42}$ fibrils and visualized by negative staining with uranyl acetate. Immunogold labeling of brain tissue sections was done after freeze substitution and low temperature resin embedding as previously described [26]. Images were recorded with a JEOL 1210 transmission electron microscope.

\section{Isolation of primary human cells and phagocytosis assay}

Monocytes were obtained from human peripheral blood mononuclear cells (PBMCs) from a buffy coat (obtained from a local blood bank) by Ficoll density centrifugation. Monocytes were isolated from PBMCs by magnetic labeling using MACS $^{\circledR}$ separation (Miltenyi Biotec, Germany \#130-091-153) that consists of the Monocyte Isolation Kit II for isolation of human monocytes through depletion of non-monocytes (negative selection). Monocytes were differentiated to macrophages by adding $0.3 \mu \mathrm{g} / \mathrm{mL}$ human macrophage colony stimulating factor (GenScript Z02001). We used differentiated human macrophages cultured in RPMI 1640 (Gibco \#61870-044) medium with $100 \mathrm{U} / \mathrm{mL}$ penicillin and $100 \mu \mathrm{g} / \mathrm{mL}$ streptomycin (Gibco \#15140-122).

Differentiated macrophages were incubated in an antibody-dependent cellular phagocytosis assay employing cryosectioned postmortem human AD brain sections as substrate. Human AD brain tissue sections from cortical regions (Braak stage VI) were prepared at a nominal thickness of $20 \mu \mathrm{m}$ and placed onto removable poly-D-lysine coated 2-well culture dishes (Biocoat ${ }^{\mathrm{TM}}$ \#40629). Brain sections were preincubated with different concentrations of gantenerumab for $1 \mathrm{~h}$, washed with PBS before human primary cells were seeded at 0.8 to $1.5 \times 10^{6}$ cells $/ \mathrm{mL}$ and cultured at $37^{\circ} \mathrm{C}$ with $5 \%$ carbon dioxide for 2 to 3 days. An unrelated human IgG1 (Serotec, PHP010) antibody was used as an additional control. Detection of amyloid- $\beta$ plaques was done after fixation with $2 \%$ formaldehyde for $10 \mathrm{~min}$, washing and staining with BAP2 conjugated to AlexaFluor 488 at $10 \mu \mathrm{g} / \mathrm{ml}$ for $1 \mathrm{~h}$ at room temperature. Double-labeling of macrophages was done with antibodies against $A \beta$ and gantenerumab as described above and lysosomal marker antibody against LAMP2 (RDI Division of Fitzgerald Industries Intl).

\section{Pharmacokinetics}

Each mouse received a single iv injection of gantenerumab at various doses. Plasma samples were analyzed for gantenerumab by a validated gantenerumab specific ELISA. Pharmacokinetic analysis was performed by standard non-compartmental analysis with the software package ToxKin 3 (Entimo AG, Berlin) using composite plasma concentration-time profiles for each dose group.

\section{RESULTS}

\section{Generation and in vitro $A \beta$ binding profile of gantenerumab}

Gantenerumab represents a new type of a fully human monoclonal anti-A $\beta$ antibody derived from a synthetic human combinatorial antibody library $\left(\mathrm{HuCAL}^{\circledR}\right.$ ) based on phage display [16]. The desired profile of the antibody was engineered successively by in vitro maturation on fibrillar $A \beta$ using reiterative cycles of CDR optimization [30] and applying targeted CDR-diversification [20]. This allowed affinity optimization for $A \beta$ binding at sub-nanomolar $K_{D}$ values. The finally selected format of gantenerumab was an IgG1 molecule of $\mathrm{Gm}(17)(\mathrm{z})$ and $\mathrm{Gm}(1)(\mathrm{a})$ allotypes [31].

Equilibrium binding of gantenerumab to different aggregation states of synthetic $A \beta_{40}$, as measured by surface plasmon resonance under conditions that monitor the bivalent binding, revealed $\mathrm{K}_{\mathrm{D}}$ values of $0.6 \mathrm{nM}$, $1.2 \mathrm{nM}$, and $17 \mathrm{nM}$ for $\mathrm{A} \beta$ fibrils, $\mathrm{A} \beta$ oligomers, and $\mathrm{A} \beta$ monomers, respectively. The kinetically most stable complex formation was observed for $A \beta$ fibrils $\left(k_{d}\right.$ 
$\left.2.8 \times 10^{-4} 1 / \mathrm{s}\right)$ and $\mathrm{A} \beta$ oligomers $\left(\mathrm{k}_{\mathrm{d}} 4.9 \times 10^{-4} 1 / \mathrm{s}\right)$ whereas for monomeric $A \beta$ a higher dissociation rate was observed $\left(\mathrm{k}_{\mathrm{d}} 1.2 \times 10^{-2} \mathrm{1} / \mathrm{s}\right)$ suggesting rapid exchange of antibody-bound monomeric $A \beta$.

Epitope mapping by pepspot analysis using overlapping decameric $A \beta$ peptides revealed that gantenerumab recognizes two regions within the $A \beta$ peptide (Fig. 1a). Reactivity was observed with peptides containing the $\mathrm{N}$-terminal sequence EFR with the decapeptide EFRHDSGYEV showing the strongest signal. A second reactivity was observed with a central region of $A \beta$ that was most pronounced with the decapeptide VFFAEDVGSN and both flanking decapeptides.

The binding of gantenerumab to the $\mathrm{N}$-terminal part of $A \beta$ was investigated in detail by $x$-ray diffraction and structural analyses. Crystallized Fab fragments of gantenerumab were soaked with peptide solutions of $A \beta_{1-11}$ or $A \beta_{3-11}$. Structures of both complexes were determined with $1.8 \AA$ and $2.0 \AA$ resolution, respectively. Only minor differences between the two complex structures were noted. The average root mean square deviation over all atoms in a superimposition of the peptides was $0.36 \AA$. Comparison of gantenerumab Fab- $A \beta$ structure with published $A \beta$ complex structures available in the Protein Data Bank
( $\mathrm{pdb}$ ) demonstrated a unique $\mathrm{A} \beta$ binding mode of gantenerumab [17-19] (Fig. 1b and c). For the heavy chain, when all Fab fragments were superimposed, gantenerumab-bound $\mathrm{A} \beta$ peptide was flipped by $180^{\circ}$. In contrast, conformations of bound $A \beta$ peptide of all published anti-A $\beta$ antibodies are markedly different. The conformational difference might be explained by the sequence differences in the CDRs between gantenerumab and the other anti-A $\beta$ antibodies published so far.

In complex with gantenerumab $A \beta_{1-11}$ is bound in an extended conformation in the groove defined by residues from the CDRs $\mathrm{H} 1, \mathrm{H} 2, \mathrm{H} 3$, and L3. All amino acids of the peptide are visible in the electron density map and participate in the interaction pattern with the heavy or light chain, at least by hydrogen bonding of the main chain nitrogen and carbonyl atoms, with the exception of Ser8 and Gly9. Both amino acids are located in a short $\gamma$-turn pointing away from the Fab fragment. The conformation of the turn is fixed by a main chain hydrogen bond between the backbone carbonyl atom of Asp7 and the backbone nitrogen of Tyr10. The first 4 residues of $A \beta_{1-11}$ are predominantly bound to the heavy chain of gantenerumab whereas residues 5 to 11 contact both heavy and light chains. Residues Asp1 and Ala2 interact with the anti-

a
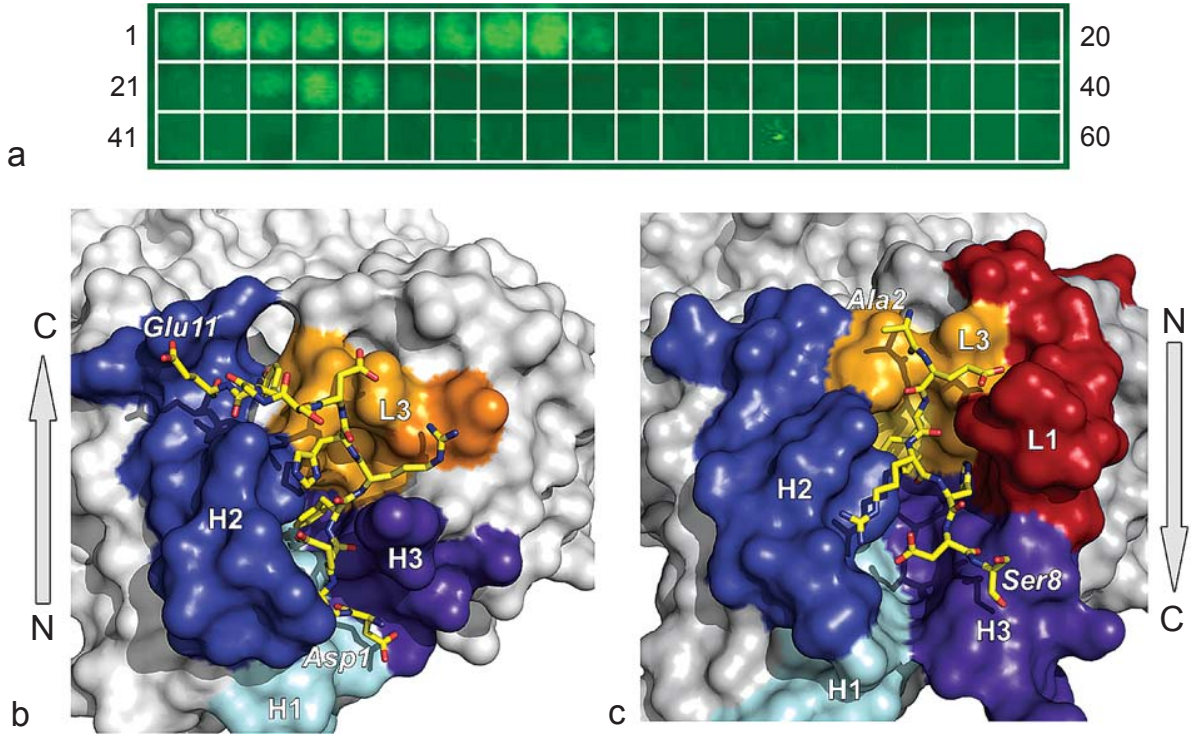

Fig. 1. Binding of gantenerumab to $A \beta$. Epitope mapping of gantenerumab by pepspot analysis with overlapping $A \beta$ decapeptides (a). Pepspot signals of numbered overlapping decapeptide spots indicate recognition of multiple amino acids at the $\mathrm{N}$-terminal and central part of $\mathrm{A} \beta$. Strongest reactivity is seen with peptides 8 (AEFRHDSGYE), 9 (EFRHDSGYEV) at the N-terminus and peptide 24 (VFFAEDVGSN) within the central part of $\mathrm{A} \beta$. Comparison of the atomic binding mode of $\mathrm{A} \beta_{1-11}$ peptide bound to gantenerumab (b) and WO2 (pdb entry $3 \mathrm{bkj}$ ) (c). The surfaces of the Fab fragments are colored in grey except the CDRs which contact the A $\beta$ peptides. H1 is shown in cyan, H2 in blue, H3 in purple, L1 in red, and L3 in orange. The orientation of the bound peptide with respect to the heavy chain is indicated by the arrow. The figure was generated with PyMOL (http://pymol.sourceforge.net/). 
body mainly by hydrogen bonds formed by main chain atoms. An anchor point for the peptide is the side chain of Phe4 that is deeply buried in a hydrophobic pocket formed by amino acids Ile92L, M95L, Ile97L, Ala33H, Met34H, Ser35H, Ala50H, Val110H, and Phe $113 \mathrm{H}$. Further tight interactions were visible for Arg5 and His6. A more detailed description of the structural analysis of gantenerumab/A $\beta$ complexes will be published elsewhere. Taken together, the crystal structure obtained from gantenerumab Fab with $A \beta_{1-11}$ or $A \beta_{3-11}$ peptides revealed a unique binding motif with frequent contacts of the $\mathrm{A} \beta$ peptides to CDRs 1 , 2 , and 3 of the heavy chain and CDR 3 of the light chain, all likely contributing to the observed high avidity for $\mathrm{A} \beta$ plaques.

Immunoelectron microscopy of brain sections labeled with gantenerumab showed specific ultrastructural localization of gold label in close proximity to fibrillar structures present in $A \beta$ plaques of $A D$ patients and transgenic PS2APP mice. (Fig. 2a and b). Specific binding to the $A \beta$ fibril surface was confirmed using synthetic $A \beta_{42}$ fibrils immunolabeled in vitro (Fig. 2c). Immunofluorescence staining revealed specific binding of gantenerumab to all types of $A \beta$ deposits. Typical dense core and diffuse $A \beta$ plaques in human AD and murine PS2APP brain tissues were specifically labeled (Fig. 2d and e). The used immunohistochemical assay employed cryosections without chemical fixatives to preserve native antigen structures and more closely mimic in vivo tissue. The minimal effective concentration of gantenerumab for consistent staining of human $\mathrm{A} \beta$ plaques was $0.07 \mathrm{nM}$ equivalent to $10 \mathrm{ng} / \mathrm{mL}$ (Fig. 2f). Our data suggest that comparable low concentrations of gantenerumab when present in brain interstitial fluid will result in effective cerebral $\mathrm{A} \beta$ binding in vivo.

\section{Gantenerumab elicits clearance of human $A \beta$ plaques ex vivo}

To test whether gantenerumab reduces $A \beta$ amyloid ex vivo, we developed a phagocytosis assay employing postmortem $\mathrm{AD}$ brain tissue slices cultured with primary human effector cells. We used differentiated primary human macrophages or primary human microglia prepared from human brain tissue after brain surgery. AD brain sections were preincubated with different concentrations of gantenerumab followed by incubation with effector cells in culture medium for $40-72 \mathrm{~h}$. A $\beta$ plaque load was assessed by immunohistochemistry and quantitative image analysis. A concentration-dependent decrease of $A \beta$ plaque load was seen (Fig. 3a-c). Notably, gantenerumab preincubated at $0.07 \mathrm{nM}(10 \mathrm{ng} / \mathrm{mL})$ was the minimal effective concentration $(p \leq 0.05)$ able to lower $\mathrm{A} \beta$ amyloid in this assay (Fig. $3 \mathrm{~b}$ and e) with amyloid removal highly significant $(p \leq 0.01$ to $p \leq 0.001)$ and almost complete after preincubation with gantenerumab at $\geq 7 \mathrm{nM}$ (Fig. 3c and e). The observed minimal effective concentration was consistent with the lowest effective concentration of gantenerumab to stain human $A \beta$ plaques (Fig. 2f). EC $_{50}$ of gantenerumab in the phagocytosis assay was around $0.7 \mathrm{nM}$ as determined in three independent experiments with macrophages from different human donors (Fig. 3f). Preincubation with gantenerumab up to $5 \mu \mathrm{g} / \mathrm{ml}$ followed by incubation in culture medium in the absence of macrophages did not influence immunoreactivity with detection antibody BAP2 excluding a competitive effect of gantenerumab in the quantification of the amyloid load (Fig. 3d). Another control experiment with unspecific human IgG1 in the presence of macrophages showed unchanged $A \beta$ load confirming that induction of phagocytic activity required gantenerumab (Fig. 3e). A similar gantenerumab dependent reduction of amyloid- $\beta$ was obtained employing primary human microglia cells [32]. Double labeling of macrophages against $A \beta$ and gantenerumab showed intracellular co-localization, demonstrating cellular uptake of gantenerumab-associated $A \beta$ (Fig. 3g-j). Double labeling of $A \beta$ and lysosomal marker LAMP2 revealed co-localization at vesicular structures indicative of lysosomal degradation of internalized $A \beta$ amyloid (Fig. 3k-n).

\section{Sustained binding of gantenerumab to $A \beta$ plaques in vivo leads to reduction of small $A \beta$ plaques}

To examine the binding of gantenerumab to $A \beta$ plaques in vivo, we administered the antibody systemically to PS2APP mice. Mice were sacrificed at various times after receiving different doses of gantenerumab and brain sections analyzed after staining against $\mathrm{A} \beta$ by confocal microscopy. Three days after dosing, the earliest time point investigated, gantenerumab was found associated with cerebral $A \beta$ plaques. Specific binding to $A \beta$ plaques was confirmed by co-localization stainings for $A \beta$. A typical image showing the reactivity of gantenerumab in PS2APP mice is shown for an immunodecorated $A \beta$ plaque at high resolution obtained after deconvolution image processing (Fig. $4 \mathrm{a}-\mathrm{c}$ ). The entire plaque surface formed by filamentous structures in the depicted $\mathrm{A} \beta$ plaque has reacted with gantenerumab. Binding of 

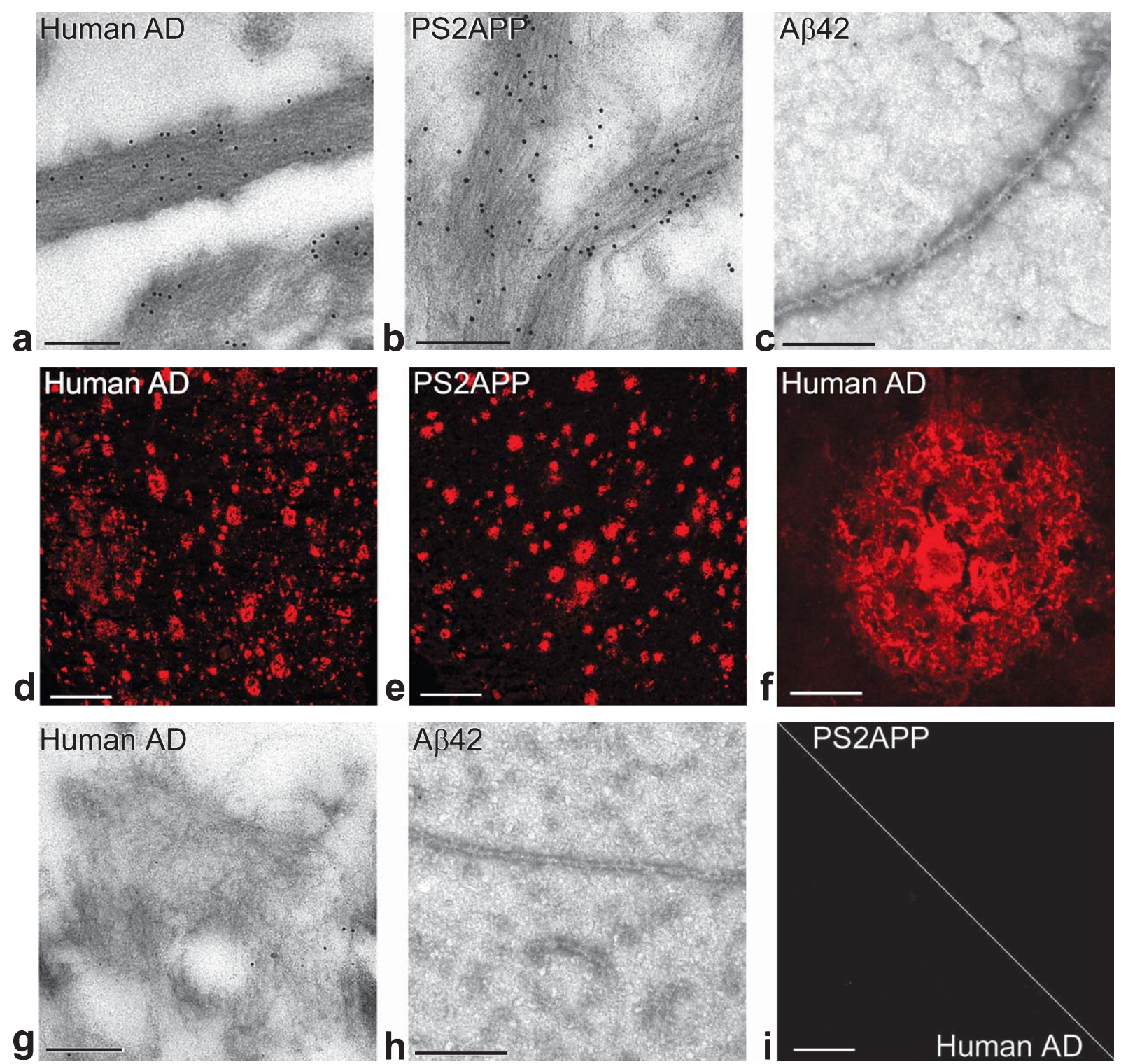

Fig. 2. Immunohistochemical localization of gantenerumab. Electron micrographs demonstrate binding of gantenerumab to $A \beta$ fibrils within amyloid- $\beta$ plaques from an AD patient (a) a PS2APP mouse (b) and synthetic A $\beta_{1-42}$ fibrils (c). Gantenerumab was detected by a secondary goat anti-human antibody conjugated to $10 \mathrm{~nm}$ colloidal gold. Immunofluorescence staining of gantenerumab at $7 \mathrm{nM}(1 \mu \mathrm{g} / \mathrm{mL})$ revealed specifically diffuse and dense-cored amyloid- $\beta$ plaques in the frontal cortex of an AD patient (d) and PS2APP mouse (e). Staining of a human AD brain section with gantenerumab at $0.07 \mathrm{nM}(10 \mathrm{ng} / \mathrm{mL})$ demonstrated sensitive reactivity with a dense-core $\mathrm{A} \beta$ plaque (f). Controls with an unrelated human IgG1 antibody were negative for human amyloid- $\beta$ plaques (g), $A \beta_{1-42}$ fibrils (h) and immunofluorescence staining of human (left) and PS2APP (right) brain tissue (i). Bars on electron microgaphs in a, b, c, g and h represent $200 \mathrm{~nm}$. Bars in fluorescence micrographs, d, e and i represent $200 \mu \mathrm{m}$ except $20 \mu \mathrm{m}$ in $\mathrm{f}$.

gantenerumab was dose-dependent with increasing fluorescence intensity at higher doses (Fig. 4d-f). Binding was observed with all $A \beta$ plaque types and in all brain regions with plaque formation, similar to the examples obtained within the frontal cortex as shown in
Fig. 4. The reactivity of gantenerumab was consistently observed in all animals investigated demonstrating effective penetration into the brain.

Microglia cells are hypothesized to be mediators of $\mathrm{A} \beta$ clearance. We therefore applied a triple label- 

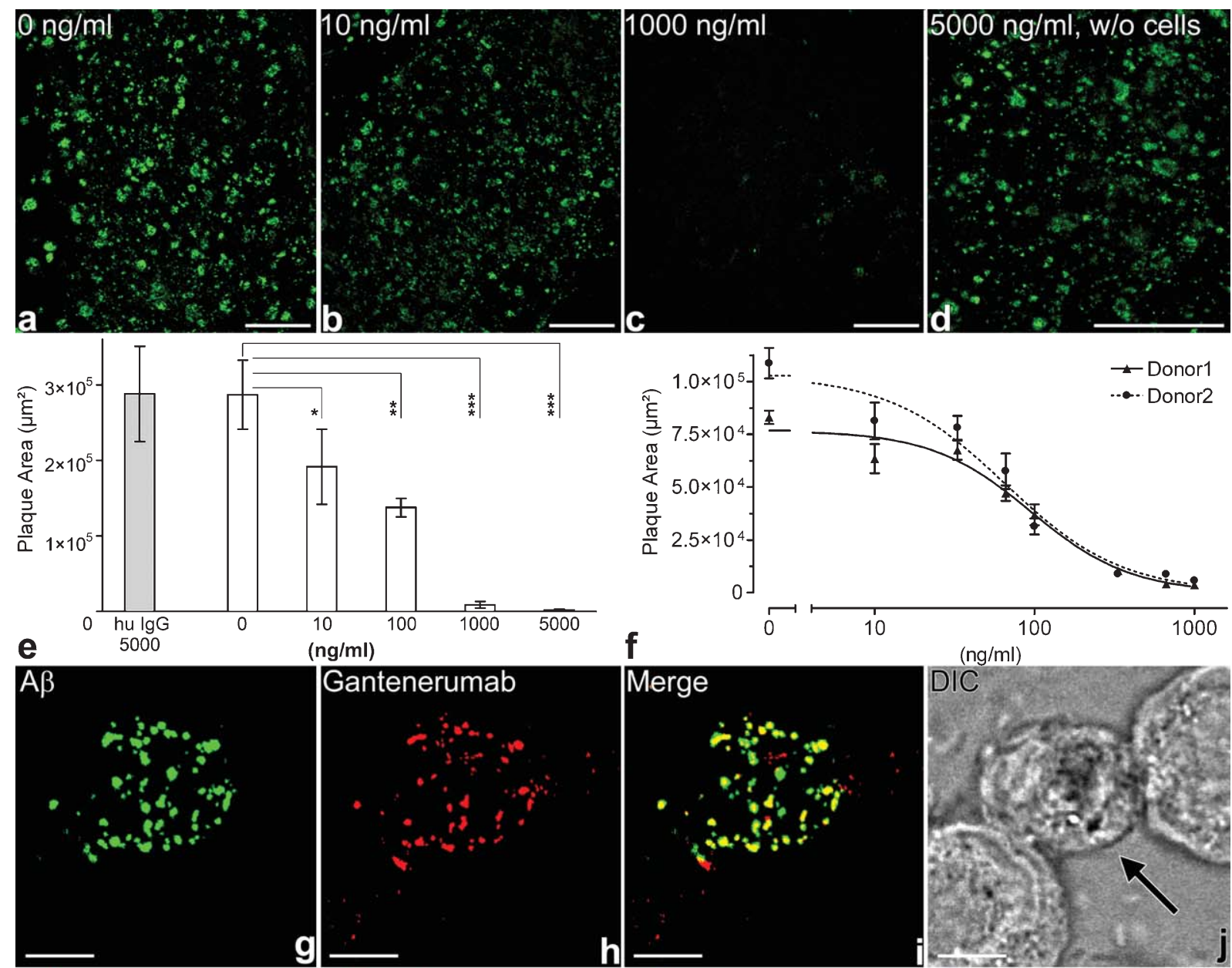

$(\mathrm{ng} / \mathrm{ml})$
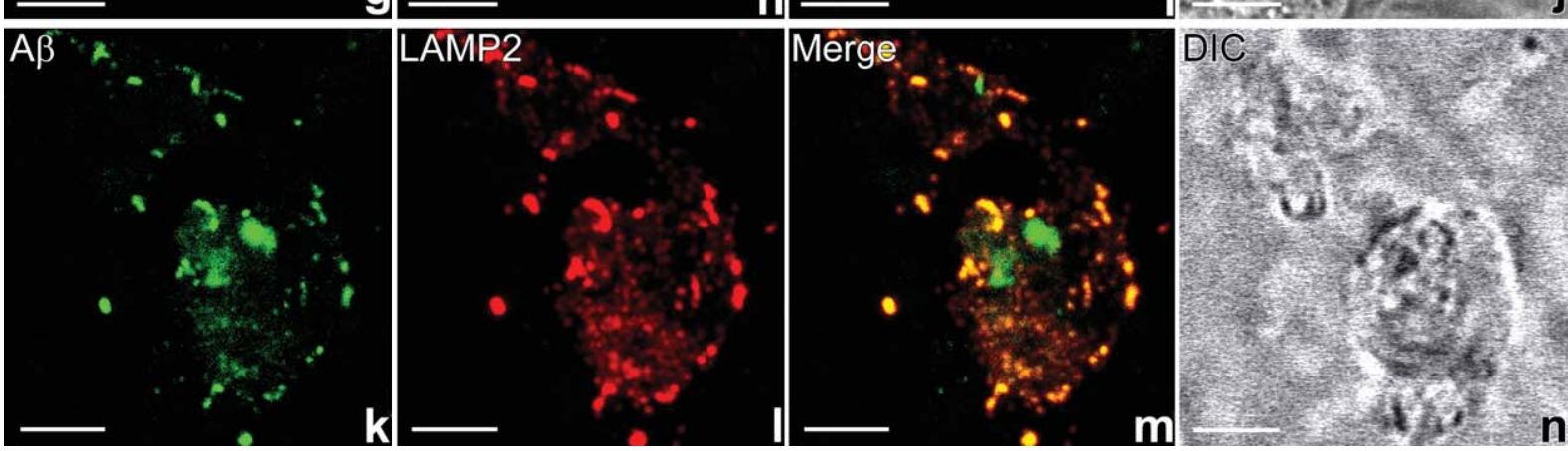

Fig. 3. Cellular phagocytosis of human amyloid- $\beta$ plaques. Human AD brain sections were preincubated with gantenerumab followed by cell culturing in presence of primary human macrophages as effector cells. Plaques were labeled afterwards with an anti-A $\beta$ antibody (BAP2) conjugated to Alexa488. Brain section without gantenerumab shows the distribution of numerous amyloid- $\beta$ plaques in the grey matter of the frontal cortical lobe after culturing with human macrophages (a) and a concentration-dependent decrease of amyloid- $\beta$ plaques when gantenerumab was added $(b$ and $c)$. Plaques were slightly reduced after preincubation with gantenerumab at $0.07 \mathrm{nM}(10 \mathrm{ng} / \mathrm{mL})(b)$ and substantially at $7 \mathrm{nM}(1,000 \mathrm{ng} / \mathrm{mL})$ (c). Control section preincubated with gantenerumab $35 \mathrm{nM}(5,000 \mathrm{ng} / \mathrm{mL})$ in the absence of cells indicated ability of BAP2 to label amyloid- $\beta$ plaques (d). Quantitative analysis of the experiment shown in $(a-c)$ revealed a significant concentrationdependent reduction of amyloid- $\beta$ plaques, while control with unrelated human IgG1 antibody is inactive (e). Determination of EC50 showed a consistent plaque clearance by macrophages from two different human donors in additional independent experiments (f). Double-staining of human macrophages for $\mathrm{A} \beta$ and gantenerumab $(\mathrm{g}-\mathrm{j})$ and $\mathrm{A} \beta$ together with the lysosomal marker LAMP2 $(\mathrm{k}-\mathrm{n})$ indicated internalization of $\mathrm{AD}$ brain derived amyloid- $\beta$ into vesicles. Differential interference contrast (DIC) images are shown for comparison to depict individual cells. The arrow in $\mathrm{j}$ points to a macrophage cell with numerous internalized complexes of colocalized $\mathrm{A} \beta$ and gantenerumab. Bars represent $300 \mu \mathrm{m}$ in $\mathrm{a}-\mathrm{d}, 5 \mu \mathrm{m}$ in $\mathrm{g}-\mathrm{j}$ and $3 \mu \mathrm{m}$ in $\mathrm{k}-\mathrm{n}$. $* p \leq 0.05, * * p \leq 0.01, * * * p 0.001$. 

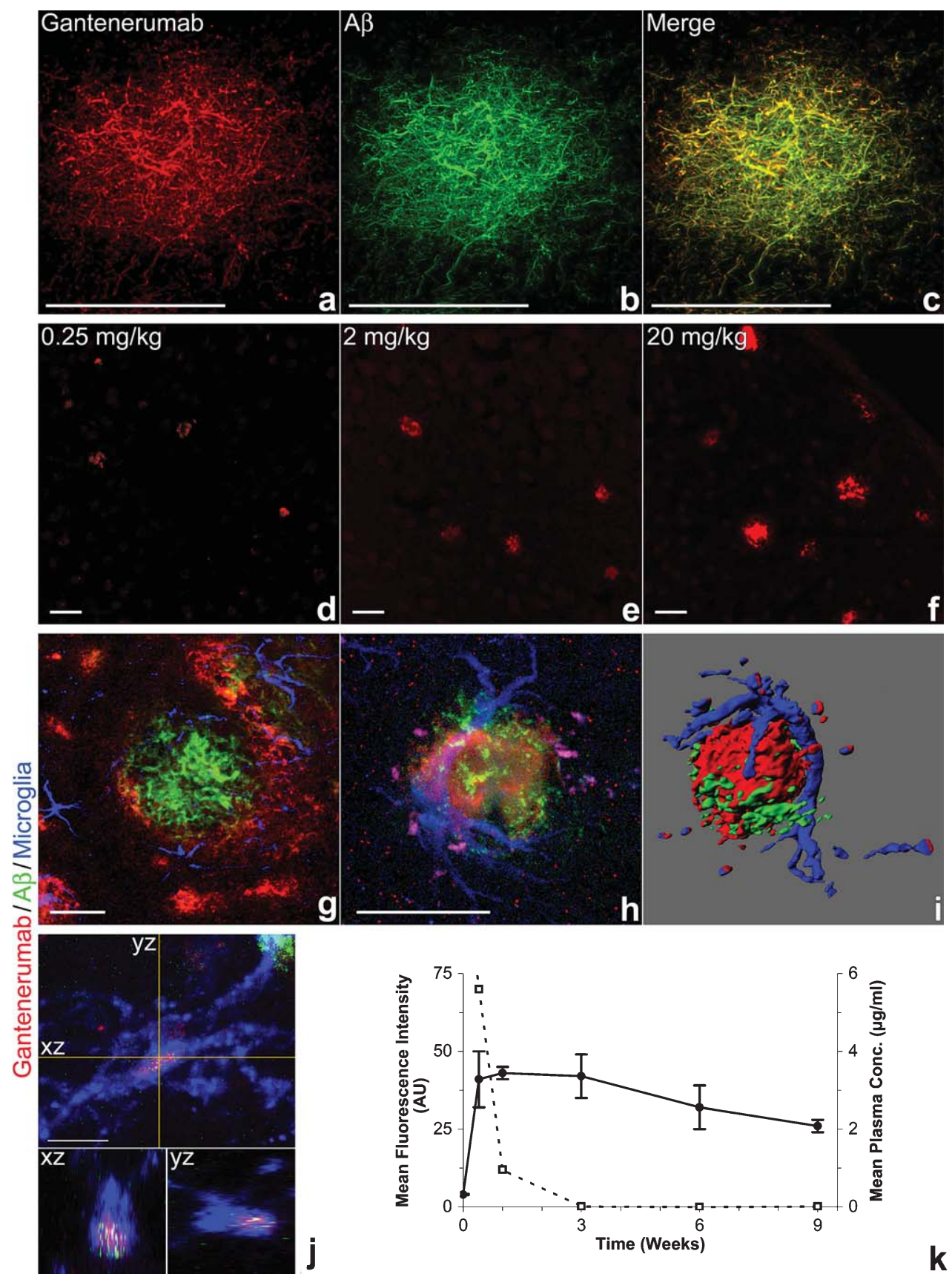

Fig. 4. Cerebral amyloid- $\beta$ plaque binding of gantenerumab in PS2APP mice. High resolution confocal microscopy image of gantenerumab binding at amyloid- $\beta$ plaque after a single iv injection of $20 \mathrm{mg} / \mathrm{kg}$ and imaging 3 days postdose (a-c). Gantenerumab was detected as described in Fig. 2. Structural details are shown after image deconvolution with strong reactivity of gantenerumab bound to an amyloid- $\beta$ plaque (a) counterstained with anti-A $\beta$ antibody BAP2 (b) demonstrating the amyloid- $\beta$ specificity by the high degree of colocalization shown in the merged image (c). Gantenerumab binds dose-dependent to plaques as shown after one week iv bolus at indicated doses (d-f). Triple labeling of gantenerumab, $\mathrm{A} \beta$ and anti- I-A/I-E-antibody revealed microglia cells adjacent to gantenerumab bound to $\mathrm{A} \beta$ deposits $(\mathrm{g})$. At higher magnification the close proximity of a microglia cell to a gantenerumab-reactive plaque $(\mathrm{h}$ ) can be appreciated and is depicted in a volumetric visualization (i) of the microglia cell shown in $\mathrm{h}$. Evidence for internalized gantenerumab that colocalized with A $\beta$ in the cytoplasm of a microglia cell is shown in three different planes of view (j). The pharmacokinetic profile of gantenerumab bound to cerebral plaques showed sustained binding in PS2APP mice (k). Values represent mean fluorescence intensity at plaques in the occipital cortex over 9 weeks after a single iv bolus dose at $20 \mathrm{mg} / \mathrm{kg}$. Error bars are $\pm \mathrm{SD}$ ( $n=3$ animals per time point). The sustained binding of gantenerumab to plaques is markedly different from its peripheral mean plasma levels (dotted line). Bars represent $25 \mu \mathrm{m}$ in a-i and $5 \mu \mathrm{m}$ in $\mathrm{j}$. 
ing procedure to visualize gantenerumab, $\mathrm{A} \beta$, and microglia. Microglia cells and microglia ramifications were frequently detected in the vicinity of plaques that reacted with gantenerumab (Fig. 4g-i). Occasionally, labeled gantenerumab and $A \beta$ was detected intracellularly in the cytoplasm of microglia cells (Fig. 4j). These findings indicate recruitment of murine microglia by gantenerumab-reactive $A \beta$ plaques and are consistent with a phagocytic plaque clearance mechanism.

To establish the kinetic profile of gantenerumab binding in vivo in the PS2APP model, we measured its reactivity with $A \beta$ plaques for up to nine weeks. There was maximal binding of gantenerumab after two to three weeks that was consistently seen with different doses in all brain regions containing plaques, i.e., cortex, hippocampus, and thalamus. The binding of gantenerumab to $A \beta$ plaques was sustained and detectable for over 2 months as shown for plaques in the frontal cortex (Fig. 4k). The minimal effective dose for detectable reactivity was $0.1 \mathrm{mg} / \mathrm{kg}$ after a single iv injection (data not shown). The pharmacokinetic profile of $\mathrm{A} \beta$-bound gantenerumab in PS2APP mice was markedly different from the peripheral presence of gantenerumab in plasma where its half-life was 6.5 days and no longer detectable after three weeks (Fig. 4k; dotted line). Our findings demonstrate a consistent and long-lasting binding of gantenerumab to $\mathrm{A} \beta$ plaques in the brain of PS2APP mice.

To test whether gantenerumab elicited a lowering of the cerebral $A \beta$ amyloid burden, we evaluated a five month treatment study in PS2APP transgenic mice. Since gantenerumab is a human antibody, mice were made tolerant by administering a single anti-CD4 injection one day before receiving gantenerumab. This treatment has been described to induce a long-lasting unresponsiveness in mice against human $\gamma$-globulin [33]. Potential anti-gantenerumab antibody responses were monitored monthly. No evidence for anti-drug antibodies was observed over the 5 months treatment period and residual plaques at the end of the study were consistently immunodecorated with gantenerumab in all animals.

Gantenerumab was administered by weekly iv bolus injections at $20 \mathrm{mg} / \mathrm{kg}$ and $A \beta$ plaque load was determined by immunostaining and morphometrical analysis in the brain regions exhibiting substantial pathology. A significant reduction of $A \beta$ amyloid plaques was evident in gantenerumab-treated PS2APP mice compared with vehicle controls (Fig. 5a and b). A detailed morphometric analysis revealed a significant $(p \leq 0.001)$ reduction of $\mathrm{A} \beta$ plaque numbers in hippocampus (36\%), neocortex $(40 \%)$, and thalamus
(70\%), respectively (Fig. 5c-e). Notably, the activity of gantenerumab correlated with plaque dimensions. The number of smaller, less than $400 \mu \mathrm{m}^{2}$, A $\beta$ plaques was most efficiently reduced when compared with vehicle treated animals (Fig. 5f). This reduction reflected not only a significant $(p \leq 0.001)$ prevention of de novo plaque formation as revealed by comparison to the vehicle treated group, but also a significant $(p \leq 0.05$ to $p \leq 0.01$ ) clearance of pre-existing small plaques up to a size range of $\leq 300 \mu \mathrm{m}^{2}$ when compared to the baseline group of PS2APP mice. The build-up of larger plaques with surfaces of $\geq 400 \mu \mathrm{m}^{2}$ was similar for both the vehicle- and gantenerumab-treated groups after the 5 month treatment period (Fig. 5f) suggesting that larger plaques were more resistant to clearance in the PS2APP mouse model used in our study. By measuring the surface fraction of stained plaques, a significant decrease $(p \leq 0.001)$ was seen in thalamus and a trend in cortex $(p=0.07)$ and hippocampus $(p=0.23)$ compared to vehicle treated animals (data not shown). Taken together these data suggested that the antibodymediated clearing rate of large plaques is too slow to compete with the rate of $A \beta$ accumulation in this aggressive transgenic mouse model of amyloidosis.

We have also analyzed the levels of both soluble and insoluble $A \beta_{40}$ and $A \beta_{42}$ in whole brain homogenates of PS2APP mice after 5 month treatment by ELISA. A small reduction of the mean levels of soluble $A \beta_{42}$ (measured per mg wet brain) was detected in the gantenerumab-treated PS2APP mice with $1.07 \pm 0.28 \mathrm{ng} / \mathrm{mg}$ (range 0.72 to $1.48 \mathrm{ng} / \mathrm{mg}$ ) versus $1.28 \pm 0.32 \mathrm{ng} / \mathrm{mg}$ (range 0.76 to $1.79 \mathrm{ng} / \mathrm{mg}$ ) in the vehicle-treated group. However, the levels for soluble $\mathrm{A} \beta_{40}$ and insoluble $\mathrm{A} \beta$ after urea dissociation were not significantly different between treatment and control groups. A relatively high variability of insoluble $A \beta$ levels among individual animals was noted in whole brain homogenates which could have masked the pronounced effect of gantenerumab on small plaques as determined by immunohistochemistry. In addition, as larger plaques $\left(\geq 400 \mu \mathrm{m}^{2}\right)$ were rather resistant to treatment, the biochemical analysis of total $A \beta$ in whole brain extracts may not be sensitive enough to reveal the observed significant reduction of smaller plaques.

A similar finding was recently reported showing that the bulk of formic acid extractable $A \beta$ was derived from dense core amyloid plaques and was not significantly affected by anti-A $\beta$ antibody treatment. However, histological analysis based on silver staining revealed a marked reduction of small and diffuse amyloid plaques [34]. 

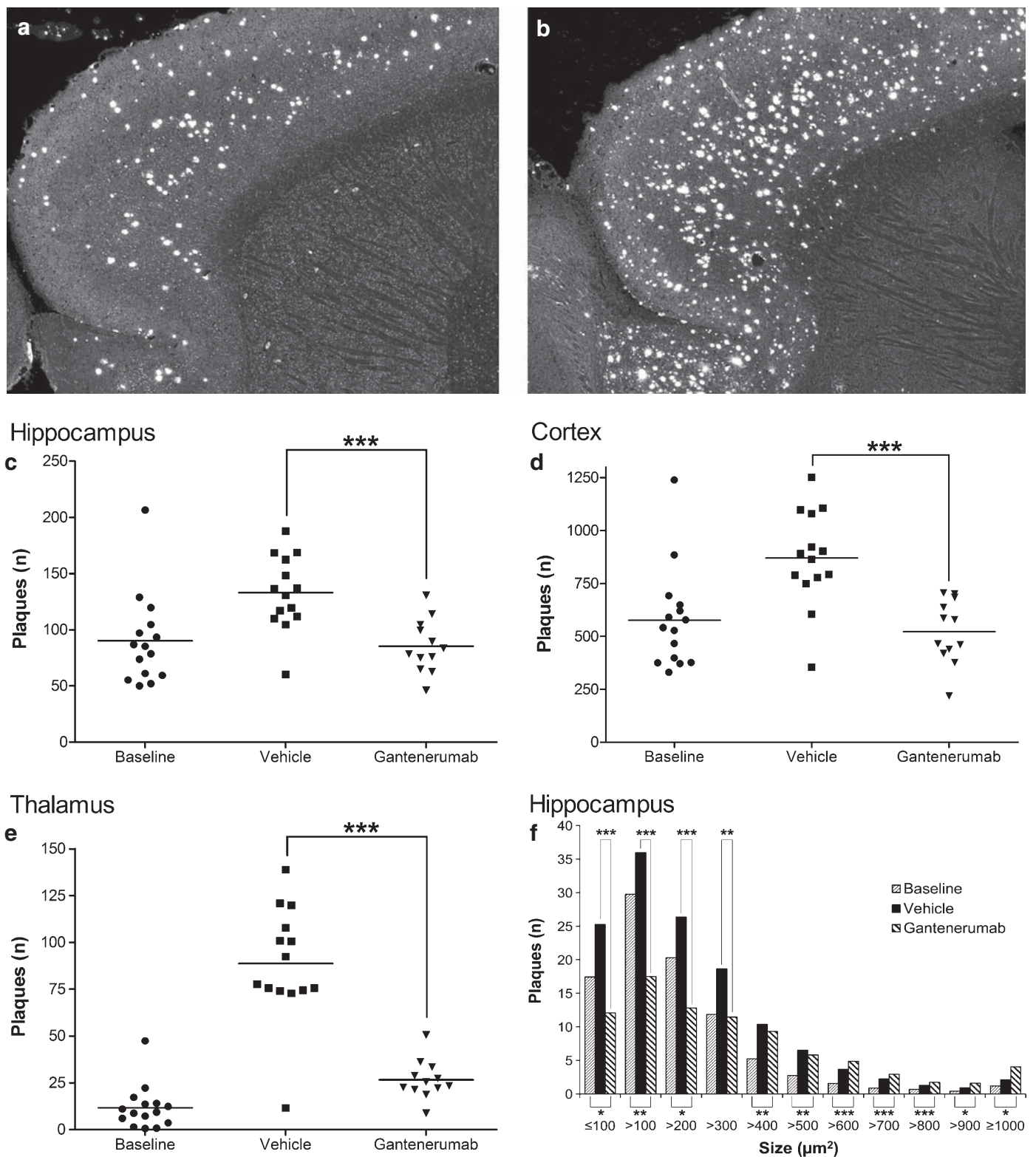

Fig. 5. PS2APP mice treated with gantenerumab for 5 months. Plaque bearing PS2APP mice were treated by weekly iv injections of gantenerumab at $20 \mathrm{mg} / \mathrm{kg}$. Reduction of $\mathrm{A} \beta$ plaques was seen after treatment with gantenerumab (a) compared with vehicle (b). Quantitative morphometry after immunohistochemical staining of $\mathrm{A} \beta$ plaques is shown for the hippocampus (c), neocortex (d) and thalamus (e). Plaque load of untreated animals sacrificed at an age of 5 months is shown for comparison as baseline level of amyloidosis at study begin (day $0, n=15$ ). A significant reduction in plaque number is evident after treatment with gantenerumab $(n=12)$, compared to the progressive plaque formation seen in vehicle treated animals $(n=14)$. A significant clearance activity of gantenerumab was seen specifically for smaller amyloid deposits up to a size of $400 \mu \mathrm{m}^{2}$ as shown for the hippocampal region (f). ${ }^{*} p \leq 0.05,{ }^{* *} p \leq 0.01, * * * p \leq 0.001$

Following 5 months of treatment with gantenerumab, there was no treatment-induced neurological or locomotor deficit and all groups learned to find the visible platform. Although no general behavioral deterioration was observed, cognitive assessment in the Morris water maze test was compromised by lack of learning in wildtype and transgenic PS2APP mice injected with vehicle (control groups) as well as in gantenerumab treated PS2APP mice. Since learning was unexpectedly impaired in the wildtype animals, a stress-induced effect caused by weekly iv injections and monthly retro-orbital blood samplings are a likely 
explanation for the observed learning deficit in the Morris water maze test.

Potential adverse effects in relation to the presence and reduction of amyloid plaques were also assessed in the five months study. No evidence of inflammatory reactions in general or other adverse effects were observed in this study. Gantenerumab was well tolerated and did not induce reactive inflammation following the degradation of $\mathrm{AD}$ plaques or exacerbate the manifestation of CAA or CAA-related microhemorrhage. Anti-gantenerumab antibodies were monitored once every month and were not detected up to the end of the study.

\section{Gantenerumab treatment does not affect peripheral A $\beta$ levels}

To study whether gantenerumab affected peripheral $A \beta$ levels, we analyzed plasma $A \beta_{40}$ and $A \beta_{42}$ after a single gantenerumab administration to PS2APP transgenic mice. For comparison we administered two murine anti-A $\beta$ antibodies which recognize either an $\mathrm{N}$-terminal epitope (BAP41) or a central epitope of $A \beta$
(BAP44) [22]. $A \beta_{40}$ and $A \beta_{42}$ plasma levels were measured 3 days after administration of the antibodies to PS2APP mice. No changes of total $A \beta_{40}$ and $A \beta_{42}$ were observed between vehicle and gantenerumab treated animals (Fig. 6). In contrast, treatment with BAP41 significantly $(p \leq 0.001)$ elevated $\mathrm{A} \beta_{40}$ and $A \beta_{42}$ concentrations by $\geq 20$ fold. Similarly, BAP44 antibody significantly $(p \leq 0.001)$ increased total $A \beta_{40}$ and $A \beta_{42}$ by 13 and 17 -fold, respectively. These data demonstrated that systemic levels of soluble $A \beta$ were not altered by gantenerumab. Presumably, due to the relatively fast off-rate of gantenerumab-bound monomeric $A \beta$ the normal degradation pathway of circulating $A \beta$ is not disturbed. A number of $A \beta$ antibodies have been described which increase total peripheral $A \beta$ levels upon administration to $A \beta P P$ transgenic animal models or AD patients. This effect is thought to be due to stabilization of circulating antibody-bound $A \beta$ interfering with the physiological systemic clearance of peripheral $A \beta$ [35].

To establish a comprehensive pharmacokinetic profile of gantenerumab in mice, exposure levels and plasma concentration-time curves were determined.
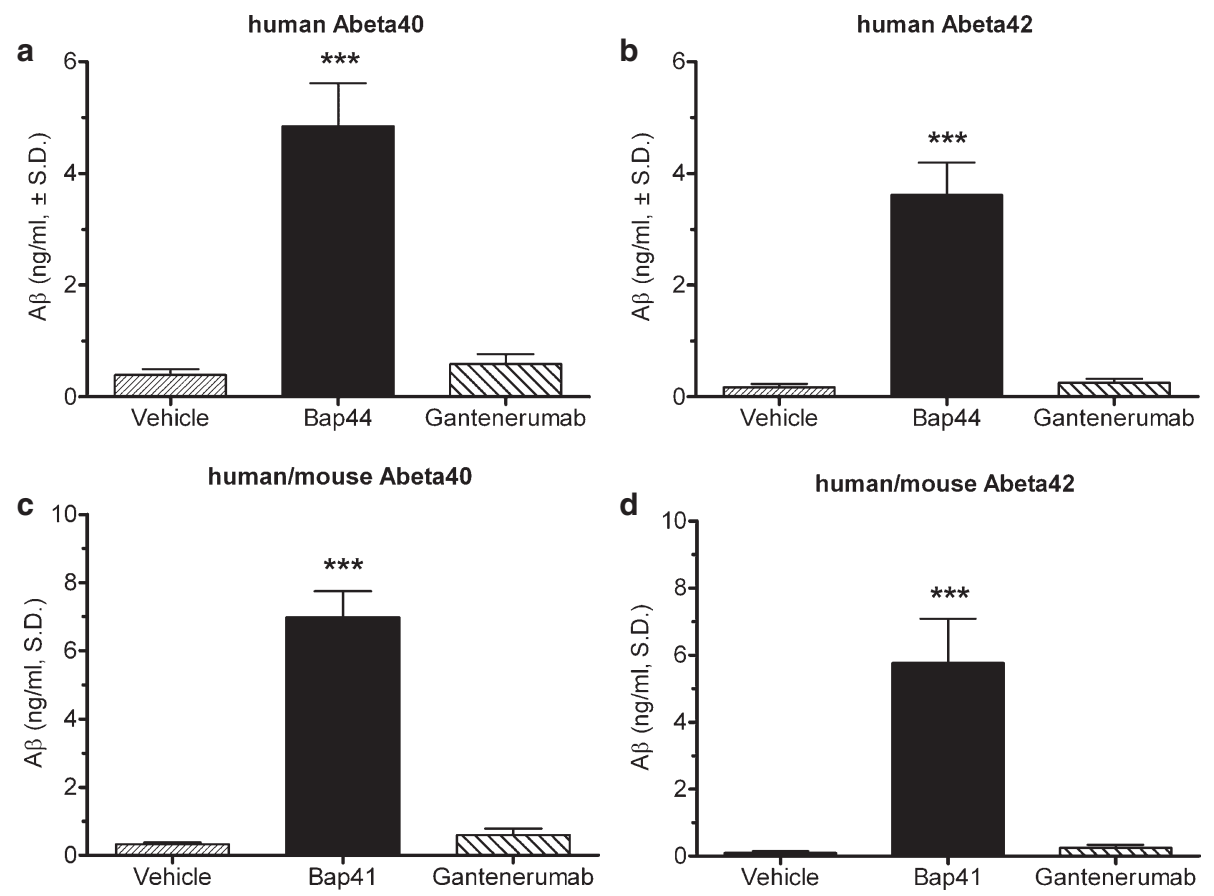

Fig. 6. Effect of gantenerumab on peripheral $A \beta_{40}$ and $A \beta_{42}$. A $\beta$ levels were determined in plasma of 4 month old PS2APP mice after a single iv injection of gantenerumab, BAP44, or BAP41 antibodies at $20 \mathrm{mg} / \mathrm{kg}$ and measured after three days. A $\beta_{40}$ and A $\beta_{42}$ were discriminated by C-terminal specific detection antibodies. BAP44 significantly increased peripheral A $\beta_{40}$ (a) and A $\beta_{42}$ (b). Likewise BAP41 also significantly elevated peripheral $A \beta_{40}$ (c) and $A \beta_{42}$ (d). Note that, in mice treated with BAP44 (recognizes $A \beta$ at position 20-21) the antibody used to capture $\mathrm{A} \beta_{40}$ and $\mathrm{A} \beta_{42}, 6 \mathrm{E} 10$, recognized the $\mathrm{N}$-terminal residues of human $\mathrm{A} \beta$ while in mice treated with $\mathrm{BAP} 41$ (recognizes $\mathrm{A} \beta$ at position 5-10), the antibody used to capture $A \beta_{40}$ and $A \beta_{42}, 4 G 8$, reacts with both human and mouse $A \beta$. Remarkably, treatment with gantenerumab did not increase peripheral $A \beta_{40}$ and $A \beta_{42}$ levels. ***p $\leq 0.001$. 
Gantenerumab exhibited a biphasic appearance in both C57BL/6 wild type and PS2APP transgenic mice with approximately dose-proportional increases in Cmax and AUC parameters. Gantenerumab was cleared slowly, with clearance values of $0.0769 \mathrm{~mL} / \mathrm{min} / \mathrm{kg}$ and $0.0667 \mathrm{~mL} / \mathrm{min} / \mathrm{kg}$ in PS2APP and wildtype C57BL/6 mice, respectively. The initial volume of distribution (Vc) was about 38 and $50 \mathrm{~mL} / \mathrm{kg}$ in PS2APP and C57BL/6 mice, respectively. The apparent volumes of distribution at steady state (Vss) were markedly higher (around $300 \mathrm{~mL} / \mathrm{kg}$ ). During the $\beta$-elimination phase, plasma concentrations decreased in a log-linear manner with a half-life of 6.5 days in PS2APP mice. Thus, similar linear pharmacokinetics profiles of gantenerumab were obtained in both PS2APP mice and C57BL/6 wild type mice, consistent with the absence of a relevant target-mediated decrease of gantenerumab in PS2APP mice expressing human A $\beta$.

\section{Gantenerumab neutralizes $A \beta_{42}$ oligomers in vivo}

To evaluate the ability of gantenerumab to neutralize neurotoxic $A \beta_{42}$ oligomers that can interfere with synaptic function, we performed LTP measurements in vivo (Fig. 7). High frequency stimulation (HFS) of the Schaffer collaterals produced post-tetanic potentiation in the CA1 region of the hippocampus of anaesthetized, adult male Sprague Dawley rats. Stable LTP was obtained after icv injection of vehicle, while injection of $A \beta_{42}$ oligomers lowered the induction of LTP after $5 \mathrm{~min}$ (Fig. 7a) and significantly $(p \leq 0.05)$ blocked LTP after $150 \mathrm{~min}$ after HFS (Fig. 7b). Co-injection of $A \beta_{42}$ oligomers with gantenerumab or $6 \mathrm{E} 10$, attenuated the inhibition of LTP induction towards control levels after vehicle injection (Fig. 7a and b). The observed capacity of gantenerumab to prevent $A \beta_{42}$-oligomer induced inhibition of LTP in rat brain suggested that gantenerumab can effectively neutralize soluble $A \beta_{42}$ aggregates and by consequence protect synaptic functionality.

\section{DISCUSSION}

Here we present the molecular and pharmacological profiles of a novel, human monoclonal IgG1 antibody, termed gantenerumab, which has been selected and optimized in vitro by phage display technologies. A number of murine anti-A $\beta$ antibodies with remarkable amyloid lowering capacities in transgenic models of $\mathrm{AD}$ have been described in the past. Some of them have been humanized and are in clinical development as potential disease-modifying therapies based on the amyloid- $\beta$ hypothesis of AD. Passive immunization holds promise for treatment of AD patients, and human rather than xenogenic antibodies are preferential choice for chronic administration.

While all of the $A \beta$ antibodies described so far, including those in clinical testing, typically bind to one region of the $A \beta$ sequence [15], gantenerumab binds to both $\mathrm{N}$-terminal and central regions of $A \beta$ as determined by solid phase peptide mapping analysis. The highest binding affinity of gantenerumab was observed for aggregated $A \beta$ states suggesting recognition of a conformational epitope constituted by $\mathrm{N}$-terminal and central $\mathrm{A} \beta$ residues in a configuration not present in
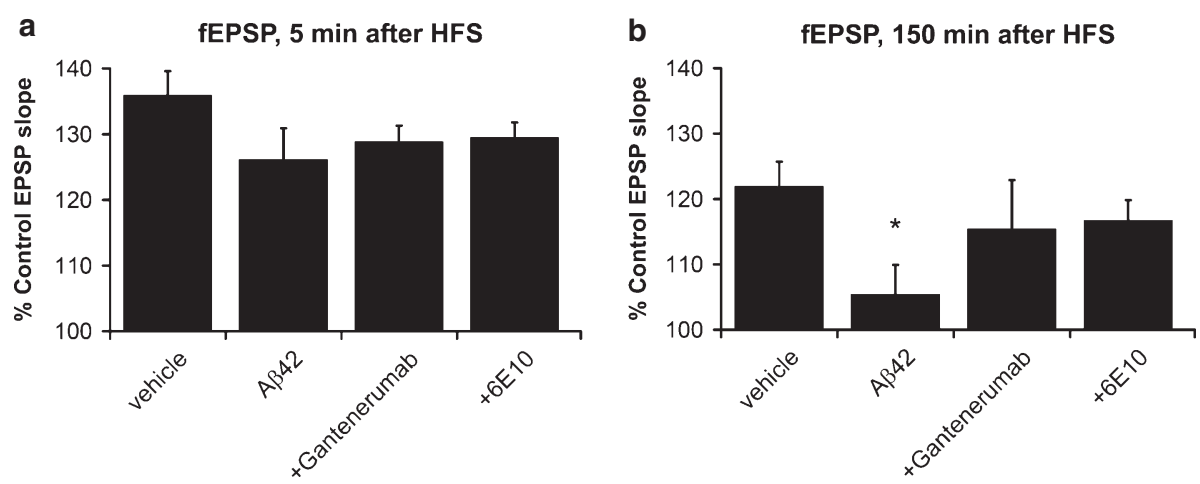

Fig. 7. Gantenerumab attenuates the inhibition of long-term potentiation (LTP) by $A \beta_{42}$ in rat CA1 in vivo. After stable baseline recordings were obtained, rats were injected icv with $5 \mu \mathrm{L}$ of vehicle or $10 \mathrm{nM} \mathrm{A} \beta_{42}$ oligomers in the absence or presence of gantenerumab or control anti-A $\beta$ antibody $6 \mathrm{E} 10$ at $1 \mu \mathrm{g} / \mu \mathrm{L}$. One hour later, high frequency stimulation (HFS) was issued that induced LTP in vehicle treated animals and in animals injected with soluble $A \beta_{42}$ oligomers co-injected with gantenerumab or 6E10. Histograms represent normalized, mean fEPSP slopes \pm SEM of 5-6 animals normalized to the 10-min period before the HFS. For comparison, mean fEPSP values are shown 5 min (a) and $150 \mathrm{~min}$ (b) after HFS with a significant blocking of LTP induction seen after injecting A $\beta_{42}$ oligomers after 150 min. Co-injection of gantenerumab or $6 \mathrm{E} 10$, effectively attenuated the $\mathrm{A} \beta_{42}$ oligomers induced inhibition of LTP induction. * $p \leq 0.05$. 
the structure of monomeric $A \beta$. Since $A \beta$ fibrils with well-defined spatial arrangement of $A \beta$ segments were used for antibody selection and maturation in vitro, the identified $A \beta$ binding properties of gantenerumab are unique and different from other antibodies raised by standard in vivo immunization procedures. These latter $\mathrm{A} \beta$ antibodies usually recognize linear epitopes of the most prominent immunogenic sequence present in the immunogen. Effective binding of gantenerumab to the supramolecular conformation of synthetic $A \beta$ fibrils was also confirmed by immuno-electron microscopy. To further elucidate the $A \beta$-binding mode of gantenerumab the structure of a gantenerumab Fab-A $\beta_{1-11}$ complex was determined by $\mathrm{x}$-ray diffraction. Interestingly, the orientation of the $\mathrm{N}$-terminal $\mathrm{A} \beta$ segment in the antigen binding cleft was opposite to what has been described for other Fab-A $\beta$ complexes [17-19]. A high resolution structure of $A \beta$ fibrils has been determined previously by NMR analysis demonstrating that the $\mathrm{N}$-terminal and central portions of $\mathrm{A} \beta$ are exposed in close juxtaposition at the surface of the fibril [36]. Based on these data and the dual epitope recognition as measured in the dot blot assay we propose a binding mode of gantenerumab to fibrillar $A \beta$ that involves both $\mathrm{N}$-terminal and spatially adjacent central $A \beta$ sequences (Fig. 8). According to this model the flexible $\mathrm{N}$-termini of $\mathrm{A} \beta$ are the initial contact points of gantnerumab binding followed by interaction with the adjacent central $A \beta$ part which confers increased binding avidity. Such a model is compatible with current structural information of $A \beta$ fibrils and the gantenerumab Fab- $A \beta_{1-11}$ complex but additional biostructural investigations are required to elucidate the exact atomic binding mode of gantenerumab to fibrillar $A \beta$.

The specificity of gantenerumab predicted strong binding to native $A \beta$ plaques. Indeed, in brain sections from AD patients and PS2APP transgenic mice, highly efficient immunostaining of fibrillar $A \beta$ was observed with gantenerumab at concentrations as low as $0.07 \mathrm{nM}$. In addition to combining specificity and high affinity binding, the therapeutic activity of anti$\mathrm{A} \beta$ antibodies may require $\mathrm{Fc}$ functionality. Here we showed that gantenerumab has the capacity to clear human $\mathrm{A} \beta$ plaques from $\mathrm{AD}$ brain slices in the presence of human primary macrophages as effector cells but not in their absence, strongly suggesting the involvement of $\mathrm{Fc}$ receptor-mediated processes. Co-staining of $\mathrm{A} \beta$, gantenerumab, and LAMP2 confirmed cellular uptake and lysosomal localization of antibody-coated A $\beta$. Notably, the minimal gantenerumab concentration to initiate $A \beta$ clearance was
$0.07 \mathrm{nM}$, i.e., the same concentration that was effective to yield significant $A \beta$ plaque binding as measured by immunostaining. Similar results were obtained with primary human microglia cells [32] further supporting the hypothesis of Fc receptor/microgliamediated phagocytosis and lysosomal degradation. Cellular phagocytosis was previously reported with murine anti-A $\beta$ antibodies applied to transgenic mouse brain sections at $10 \mu \mathrm{g} / \mathrm{mL}(\sim 70 \mathrm{nM})$ and cultured with primary murine microglia cells [10]. Differences in the assay conditions, higher binding affinity and/or mode of conformational epitope recognition might account for the several orders of magnitude higher potency of gantenerumab in the human ex vivo assay compared to the published murine assay results.

Immunoglobulins reach $\mathrm{CSF} /$ plasma ratios of 0.1 to $0.2 \%[37,38]$ predicting that efficacious brain interstitial fluid concentrations of gantenerumab, i.e., in the subnanomolar range based on the ex vivo phagocytosis experiments, can be achieved at attainable plasma levels. While the exact mechanism of amyloid- $\beta$ clearance is still a matter of debate, our data and earlier studies in transgenic mice [10] and AD patients [5, 6] suggest that microglia-mediated phagocytosis of antibody-coated $A \beta$ plaques is a major mechanism of $A \beta$ plaque clearance in the brain. In addition it is possible that other innate immune mechanisms such as complement activation also contribute to the clearance of amyloid- $\beta$ plaques in vivo. Stimulation of microglia by $A \beta$-bound antibodies may be particularly efficient in $\mathrm{AD}$ patients who are compromised by dysfunctional macrophages and pathologically altered microglia with poor capacity to degrade $A \beta[39,40]$. A vaccination study in vervet monkeys also supported the role of brain penetrating anti- $\mathrm{A} \beta$ antibodies in $\mathrm{A} \beta$ clearance since therapeutically active antibodies raised in these animals showed significant reactivity against fibrillar $\mathrm{A} \beta$ [41, 42].

Only partial and/or transient $A \beta$ plaque reactivity, most prominent $1 \mathrm{~h}$ after injection, has been reported for murine anti-A $\beta$ antibodies investigated in transgenic mouse models [43, 44]. In contrast, gantenerumab showed sensitive, dose-dependent and sustained binding to $A \beta$ plaques in the brains of PS2APP mice that lasted more than 9 weeks after single administration indicating an extraordinary thermodynamic binding stability towards amyloid- $\beta$ plaques in vivo. It is interesting to note that despite this significant "decoration" of $\mathrm{A} \beta$ plaques by gantenerumab large plaques $\left(>400 \mu \mathrm{m}^{2}\right)$ were relatively resistant to clearance as evident from the 5-months treatment study. Whether attenuated interactions of human $\mathrm{Fc}$ with 


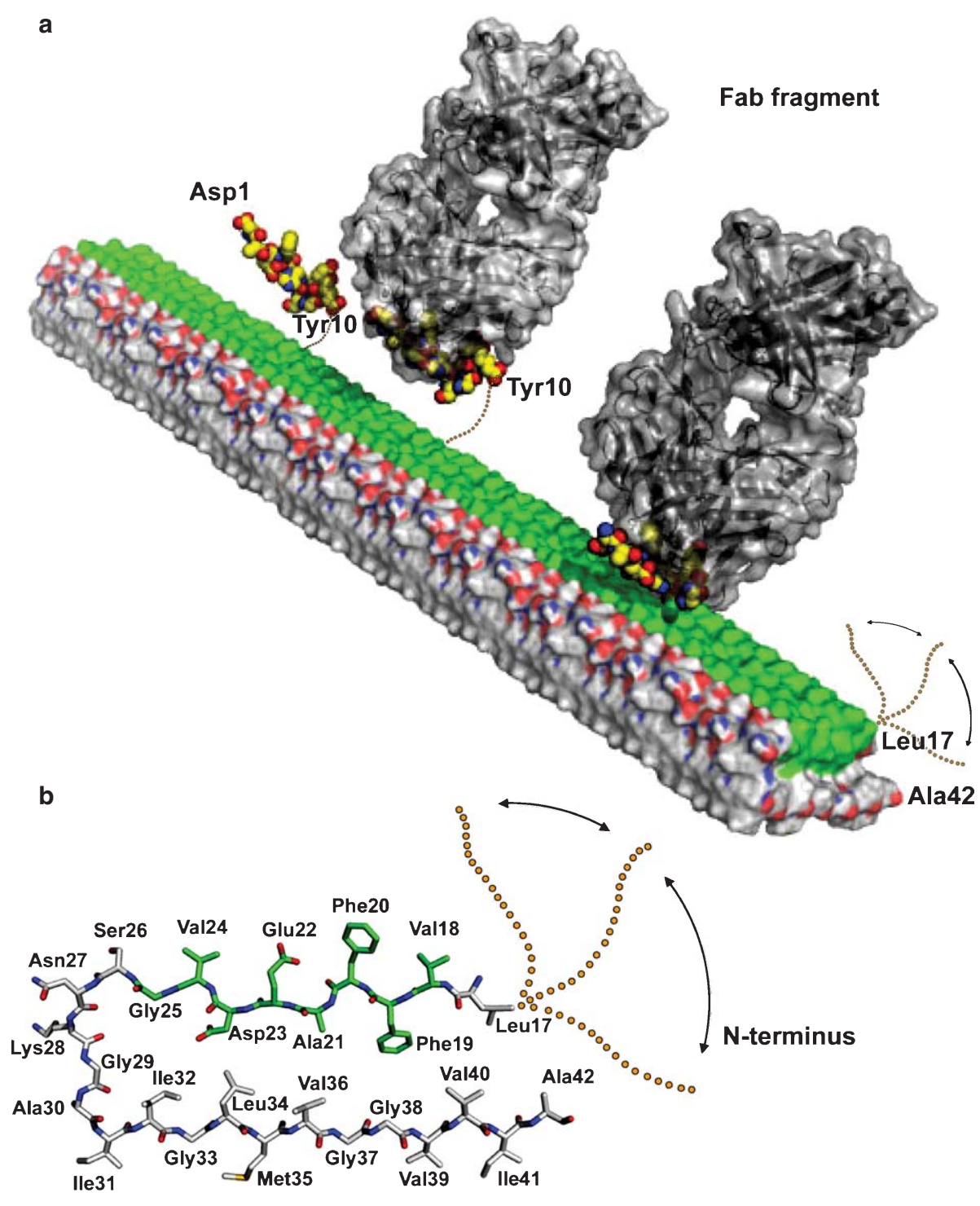

Fig. 8. Model of gantenerumab binding to the $A \beta$ fibril surface. The binding of the gantenerumab Fab fragments to the $A \beta$ fibril is schematically shown in a stepwise manner from left to right (a). The N-terminal part of $A \beta$ is shown according to the atomic binding data obtained with gantenerumab shown for $\mathrm{A} \beta_{1-10}$ (DAEFRHDSGY). Initial binding to this free $\mathrm{N}$-terminal part is followed in a second step involving the central A $\beta$ epitope comprising amino acids 19-26 (VFFAEDVG) with their position highlighted in green on the fibril surface; the remaining surface is colored according to atom type with nitrogen and oxygen shown in blue and red. This dual mode of interaction is considered feasible by the spatial vicinity of both epitopes at the fibril surface and the flexibility of the N-terminus of $\mathrm{A} \beta$. By consequence, an increased avidity of gantenerumab to fibrillar $A \beta$ is suggested even in the presence of $\mathrm{N}$-terminal truncated $\mathrm{A} \beta$. The presented fibril structure is derived from data obtained by the NMR study by Lührs et al. [36]. A crossectional view perpendicular to the fibril axis showing one $\beta$-strand ordered stretch of $\mathrm{A} \beta_{17-42}$ with amino acids at position 19-26 shown in green (b). The approximate position of the flexible $\mathrm{N}$-terminus at Leu17 is schematically illustrated with dotted lines in $a$ and $b$.

murine microglia or other mechanisms contribute to the apparent persistence of these larger amyloid- $\beta$ plaques needs further investigation. However, gantenerumab clearly elicited clearance of small-sized $\mathrm{A} \beta$ plaques and inhibited formation of new plaques after chronic treatment of PS2APP mice. A similar long-lasting binding of a murine anti-A $\beta$ antibody to amyloid plaques and resistance of thioflavine-Spositive dense cored plaques to antibody-mediated clearance was recently reported [34].

It is known that human IgG1 Fc binds less efficiently to murine Fc $\gamma$ receptors [45] and activation of phagocytosis by microglia might not be optimally supported by a human IgG1 antibody like gantenerumab in a 
murine animal model. While murine anti-A $\beta$ antibodies have repeatedly been shown to lower amyloid- $\beta$ load in a variety of transgenic mouse models likely involving activated microglia [46, 47], our study is the first to confirm the amyloid-lowering capacity of a fully human antibody in a transgenic mouse model. Gantenerumab is a human IgG1 which functionally corresponds to the murine IgG2a subtype. Murine IgG2a anti-A $\beta$ antibody subtypes were shown to induce cellular phagocytosis and lower thioflavinS positive amyloid plaques [48, 49]. In this context, a recent comparative study between murine 3D6 (IgG2a) and murine $\mathrm{m} 266$ (IgG1) anti-A $\beta$ antibodies did not confirm removal of brain amyloid by $\mathrm{m} 266$ whereas the $A \beta$ plaque binding 3D6 antibody was effective [50]. Besides the differences of the two antibodies in amyloid recognition (plaque-binding 3D6 versus $A \beta$ peptide-capturing $\mathrm{m} 266$ ), the murine $\mathrm{IgG1}$ isotype of m266 may also have contributed to the lack of efficacy in this model. In conclusion, the observed strong binding capacity of gantenerumab to amyloid plaques holds promise for effective treatment of human AD patients, in line with the notion that therapeutic efficacy likely requires the use of an antibody that can optimally cross the blood-brain-barrier [51].

Remarkably, gantenerumab did not increase peripheral $A \beta_{40}$ or $A \beta_{42}$ levels in PS2APP mice whereas massive increases of plasma $A \beta$ have been reported for murine $\mathrm{m} 266$ and 3D6 antibodies in transgenic models $[11,50]$. Both 3D6 and m266 when converted into humanized antibodies showed marked elevation of peripheral $A \beta$ in $\mathrm{AD}$ patients $[15,52]$. The similarity in the pharmacokinetic profiles of investigated anti- $A \beta$ antibodies and $A \beta$ indicates a stabilization of soluble $A \beta$ by binding to the circulating anti-A $\beta$ antibodies $[35,53]$. In contrast to these antibodies, gantenerumab did not stabilize soluble $A \beta$ in the periphery or in the brain, where binding to aggregated $A \beta$ is thermodynamically preferred. Therefore, soluble monomeric $A \beta$ does not compete with gantenerumabbinding to $A \beta$ plaques in vivo but may interfere with $3 \mathrm{D} 6$ or $\mathrm{m} 266$ binding to aggregated $\mathrm{A} \beta$ once stable complexes with soluble monomeric $A \beta$ are formed. Impaired receptor-mediated efflux of antibody-bound $\mathrm{A} \beta$ by FcRn receptors in the brain [14] appears less likely to account for the observed lack of peripheral $A \beta$ increase in presence of gantnerumab since recent studies comparing wt and FcRn knockout mice suggest that $\mathrm{FcRn}$ does not significantly contribute to transport of $\operatorname{IgG}$ across the blood-brain-barrier in mice [54]. Our findings support the concept that amyloid- $\beta$ lowering requires brain uptake of antibody and binding to cerebral amyloid. However, in addition to microglia-mediated $A \beta$ clearance through activation of $\mathrm{Fc} \gamma$ receptors it cannot be excluded that either direct dissociation of aggregated $A \beta[12,55]$ or other Fc independent pathways also contribute to some extent to $A \beta$ lowering in vivo [56-58].

Similar to the N-terminal specific anti-A $\beta$ antibody $6 \mathrm{E} 10$, gantenerumab was also shown to neutralize $\mathrm{A} \beta_{42}$ oligomer-induced inhibition of LTP in rat brain confirming previous reports $[13,59]$. Thus, consistent with the high avidity binding to aggregated $A \beta_{42}$, gantenerumab can functionally neutralize oligomeric $A \beta_{42}$. The ability of gantenerumab to react not only with the $A \beta$ fibrils and plaques but also with oligomeric $\mathrm{A} \beta$ might contribute to its therapeutic use by restoring synaptic deficits that are known to occur in AD.

In our studies in PS2APP mice after chronic treatment with gantenerumab, we did not observe an increased incidence of cerebral $A \beta$ angiopathy (CAA) or microhemorrhages. Previous reports attributed these vascular side effects either to the epitope specificity of the anti-A $\beta$ antibody, exemplified by the $\mathrm{N}$-terminal specific 3D6 antibody [60] or the Fc glycosylation pattern [57]. However, the relevance of these observations for immunotherapy in $\mathrm{AD}$ patients is not established. Intriguingly, histopathological evaluations of postmortem AD brains in follow-up studies of the AN1792 trial suggested that increased CAA pathology observed in immunized patients may be due to a transient perturbation of the perivascular drainage pathway [61].

In summary, our findings provide evidence that the specificity and avidity of gantenerumab facilitates sustained binding to cerebral $A \beta$ in vivo leading to reduction of the amyloid plaque burden by triggering effector cell-mediated clearance mechanisms. Thus gantenerumab represents a potent human anti- $A \beta$ antibody with a preference for aggregated $A \beta$ and is considered as a promising agent for disease-modifying interventions in $\mathrm{AD}$.

\section{ACKNOWLEDGMENTS}

We thank Claudia Richardson for her support in brain sectioning and performing immunohistochemical stainings. Dr. Marcel Zocher provided valuable expertise for monocyte enrichment and macrophage differentiation. Technical support was provided by Andrea Wiget who measured binding parameters with Biacore, Robert Schubenel for $A \beta$ determinations by LPECL and Dominique Burger purifying the Fab fragments for x-ray crystallography. Dr. Corinna Löhning 
and Dr. Stefan Steidl contributed significantly to antibody selection and affinity maturation, respectively. The expert support from Dr. Helmut Jacobsen, Christoph Schweitzer, Dr. Juergen Schlaeger, Dr. Diana Schuhbauer, Dr. Erhard Kopetzki, Dr. Kay Stubenrauch, and Dr. Andreas Schaubmar for recombinant expression, technical production and assay development for gantenerumab is greatly acknowledged. We further thank Dr. Laurence Ozmen for biochemical analysis of A $\beta$ by ELISA and especially Dr. Manfred Brockhaus for his expertise in epitope mapping. Finally, we thank Dr. Howard Ettlinger and Dr. Juha Savola for critical reading of the manuscript.

Authors' disclosures available online (http://www.jalz.com/disclosures/view.php?id=972).

\section{REFERENCES}

[1] Hardy J, Selkoe DJ (2002) The amyloid hypothesis of Alzheimer's disease: Progress and problems on the road to therapeutics. Science 297, 353-356.

[2] Schenk D, Barbour R, Dunn W, Gordon G, Grajeda H, Guido T, Hu K, Huang J, Johnson-Wood K, Khan K, Kholodenko D, Lee M, Liao Z, Lieberburg I, Motter R, Mutter L, Soriano F, Shopp G, Vasquez N, Vandevert C, Walker S, Wogulis M, Yednock T, Games D, Seubert P (1999) Immunization with amyloid-beta attenuates Alzheimer-disease-like pathology in the PDAPP mouse. Nature 400, 173-177.

[3] Janus C, Pearson J, McLaurin J, Mathews PM, Jiang Y, Schmidt SD, Chishti MA, Horne P, Heslin D, French J, Mount HT, Nixon RA, Mercken M, Bergeron C, Fraser PE, St George-Hyslop P, Westaway D (2000) A beta peptide immunization reduces behavioural impairment and plaques in a model of Alzheimer's disease. Nature 408, 979-982.

[4] Orgogozo JM, Gilman S, Dartigues JF, Laurent B, Puel M, Kirby LC, Jouanny P, Dubois B, Eisner L, Flitman S, Michel BF, Boada M, Frank A, Hock C (2003) Subacute meningoencephalitis in a subset of patients with AD after Abeta42 immunization. Neurology 61, 46-54.

[5] Nicoll JA, Wilkinson D, Holmes C, Steart P, Markham H, Weller RO (2003) Neuropathology of human Alzheimer disease after immunization with amyloid-beta peptide: A case report. Nat Med 9, 448-452.

[6] Boche D, Zotova E, Weller RO, Love S, Neal JW, Pickering RM, Wilkinson D, Holmes C, Nicoll JA (2008) Consequence of Abeta immunization on the vasculature of human Alzheimer's disease brain. Brain 131, 3299-3310.

[7] Gilman S, Koller M, Black RS, Jenkins L, Griffith SG, Fox NC, Eisner L, Kirby L, Rovira MB, Forette F, Orgogozo JM (2005) Clinical effects of Abeta immunization (AN1792) in patients with AD in an interrupted trial. Neurology 64, 15531562.

[8] Holmes C, Boche D, Wilkinson D, Yadegarfar G, Hopkins V, Bayer A, Jones RW, Bullock R, Love S, Neal JW, Zotova E, Nicoll JA (2008) Long-term effects of Abeta42 immunisation in Alzheimer's disease: Follow-up of a randomised, placebocontrolled phase I trial. Lancet 372, 216-223.
[9] Vellas B, Black R, Thal LJ, Fox NC, Daniels M, McLennan G, Tompkins C, Leibman C, Pomfret M, Grundman M (2009) Long-term follow-up of patients immunized with AN1792: Reduced functional decline in antibody responders. Curr Alzheimer Res 6, 144-151.

[10] Bard F, Cannon C, Barbour R, Burke RL, Games D, Grajeda H, Guido T, Hu K, Huang J, Johnson-Wood K, Khan K, Kholodenko D, Lee M, Lieberburg I, Motter R, Nguyen M, Soriano F, Vasquez N, Weiss K, Welch B, Seubert P, Schenk D, Yednock T (2000) Peripherally administered antibodies against amyloid beta-peptide enter the central nervous system and reduce pathology in a mouse model of Alzheimer disease. Nat Med 6, 916-919.

[11] DeMattos RB, Bales KR, Cummins DJ, Dodart JC, Paul SM, Holtzman DM (2001) Peripheral anti-A beta antibody alters CNS and plasma A beta clearance and decreases brain A beta burden in a mouse model of Alzheimer's disease. Proc Natl Acad Sci U S A 98, 8850-8855.

[12] Solomon B, Koppel R, Hanan E, Katzav T (1996) Monoclonal antibodies inhibit in vitro fibrillar aggregation of the Alzheimer beta-amyloid peptide. Proc Natl Acad Sci U S A 93, 452-455.

[13] Du Y, Wei X, Dodel R, Sommer N, Hampel H, Gao F, Ma Z, Zhao L, Oertel WH, Farlow M (2003) Human antibeta-amyloid antibodies block beta-amyloid fibril formation and prevent beta-amyloid-induced neurotoxicity. Brain 126, 1935-1939.

[14] Deane R, Sagare A, Hamm K, Parisi M, LaRue B, Guo H, Wu Z, Holtzman DM, Zlokovic BV (2005) IgG-assisted agedependent clearance of Alzheimer's amyloid beta peptide by the blood-brain barrier neonatal Fc receptor. J Neurosci 25, 11495-11503.

[15] Bednar MM (2009) Anti-amyloid antibody drugs in clinical testing for Alzheimer's disease. IDrugs 12, 566-575.

[16] Rauchenberger R, Borges E, Thomassen-Wolf E, Rom E, Adar R, Yaniv Y, Malka M, Chumakov I, Kotzer S, Resnitzky D, Knappik A, Reiffert S, Prassler J, Jury K, Waldherr D, Bauer S, Kretzschmar T, Yayon A, Rothe C (2003) Human combinatorial Fab library yielding specific and functional antibodies against the human fibroblast growth factor receptor 3. J Biol Chem 278, 38194-38205.

[17] Miles LA, Wun KS, Crespi GA, Fodero-Tavoletti MT, Galatis D, Bagley CJ, Beyreuther K, Masters CL, Cappai R, McKinstry WJ, Barnham KJ, Parker MW (2008) Amyloidbeta-anti-amyloid-beta complex structure reveals an extended conformation in the immunodominant B-cell epitope. $J \mathrm{Mol}$ Biol 377, 181-192.

[18] Gardberg A, Dice L, Pridgen K, Ko J, Patterson P, Ou S, Wetzel R, Dealwis C (2009) Structures of Abeta-related peptide-monoclonal antibody complexes. Biochemistry 48, 5210-5217.

[19] Basi GS, Feinberg H, Oshidari F, Anderson J, Barbour R, Baker J, Comery TA, Diep L, Gill D, Johnson-Wood K, Goel A, Grantcharova K, Lee M, Li J, Partridge A, GriswoldPrenner I, Piot N, Walker D, Widom A, Pangalos MN, Seubert P, Jacobsen JS, Schenk D, Weis WI (2010) Structural correlates of antibodies associated with acute reversal of amyloid beta-related behavioral deficits in a mouse model of Alzheimer disease. J Biol Chem 285, 3417-3427.

[20] Steidl S, Ratsch O, Brocks B, Durr M, Thomassen-Wolf E (2008) In vitro affinity maturation of human GM-CSF antibodies by targeted CDR-diversification. Mol Immunol 46, 135-144.

[21] Rüfenacht P, Güntert A, Bohrmann B, Ducret A, Döbeli H (2005) Quantification of the A beta peptide in Alzheimer's 
plaques by laser dissection microscopy combined with mass spectrometry. J Mass Spectrometry 40, 193-201.

[22] Brockhaus M, Ganz P, Huber W, Bohrmann B, Loetscher HR, Seelig J (2007) Thermodynamic studies on the interaction of antibodies with beta-amyloid peptide. J Phys Chem 111, 1238-1243.

[23] Stine WB Jr, Dahlgren KN, Krafft GA, LaDu MJ (2003) In vitro characterization of conditions for amyloid-beta peptide oligomerization and fibrillogenesis. J Biol Chem 278, 1161211622.

[24] The CCP4 suite (1994) Programs for protein crystallography. Acta Crystallogr D Biol Crystallogr 50, 760-763.

[25] Emsley P, Lohkamp B, Scott WG, Cowtan K. Features and development of Coot. Acta Crystallogr D Biol Crystallogr 66, 486-501.

[26] Richards JG, Higgins GA, Ouagazzal AM, Ozmen L, Kew JN, Bohrmann B, Malherbe P, Brockhaus M, Loetscher H, Czech C, Huber G, Bluethmann H, Jacoben H, Kemp JA (2003) PS2APP transgenic mice, coexpressing hPS2mut and hAPPswe, show age-related cognitive deficits associated with discrete brain amyloid deposition and inflammation. $\mathrm{J} \mathrm{Neu}$ rosci 23, 8989-9003.

[27] Waldmann H, Adams E, Cobbold S (2008) Reprogramming the immune system: Co-receptor blockade as a paradigm for harnessing tolerance mechanisms. Immunol Rev 223, 361370.

[28] Narlawar R, Pérez-Revuelta BI, Haas C, Steiner H, Baumann K (2006) Scaffold of the cyclooxygenase-2 (COX-2) inhibitor carprofen provides Alzheimer gamma-secretase modulators. J Med Chem 49, 7588-7591.

[29] Braak H, Braak E (1991) Neuropathological stageing of Alzheimer-related changes. Acta Neuropathol 82, 239-259.

[30] Yang WP, Green K, Pinz-Sweeney S, Briones AT, Burton DR, Barbas CF (1995) CDR walking mutagenesis for the affinity maturation of a potent human anti-HIV-1 antibody into the picomolar range. J Mol Biol 254, 392-394.

[31] Jefferis R, Lefranc MP (2009) Human immunoglobulin allotypes: Possible implications for immunogenicity. MAbs $\mathbf{1}$, 332-338.

[32] Ostrowitzki S, Deptula D, Thurfjell L, Barkhof F, Bohrmann B, Brooks DJ, William Klunk WE, Ashford E, Yoo K, Xu ZX, Loetscher H, Santarelli L (2011) Mechanism of amyloid removal in patients with Alzheimer's disease treated with gantenerumab. Arch Neurol, doi: 10.1001/archneurol.2011. 1538 .

[33] Benjamin RJ, Waldmann H (1986) Induction of tolerance by monoclonal antibody therapy. Nature 320, 449-451.

[34] Wang A, Das P, Switzer RC, Golde TE, Jankowsky JL (2011) Robust amyloid clearance in a mouse model of Alzheimer's disease provides novel insights into the mechanism of amyloid-beta immunotherapy. J Neurosci 31, 41244136.

[35] Golde TE, Das P, Levites Y (2009) Quantitative and mechanistic studies of Abeta immunotherapy. CNS Neurol Disord Drug Targets 8, 31-49.

[36] Lührs T, Ritter C, Adrian M, Riek-Loher D, Bohrmann B, Döbeli H, Schubert D, Riek R (2005) 3D structure of Alzheimer's amyloid-beta(1-42) fibrils. Proc Natl Acad Sci U S A 102, 17342-17347.

[37] Broadwell RD, Sofroniew MV (1993) Serum proteins bypass the blood-brain fluid barriers for extracellular entry to the central nervous system. Exp Neurol 120, 245-263.

[38] Poduslo JF, Curran GL, Berg CT (1994) Macromolecular permeability across the blood-nerve and blood-brain barriers. Proc Natl Acad Sci U S A 91, 5705-5709.
[39] Fiala M, Rosenthal M, Bernard G (2007) Phagocytosis of amyloid-beta and inflammation: Two faces of innate immunity in Alzheimer's disease. J Alzheimers Dis 11, 457-463.

[40] Boche D, Nicoll JA (2008) The role of the immune system in clearance of Abeta from the brain. Brain Pathol 18, 267-278.

[41] Lemere CA, Beierschmitt A, Iglesias M, Spooner ET, Bloom JK, Leverone JF, Zheng JB, Seabrook TJ, Louard D, Li D, Selkoe DJ, Palmour RM, Ervin FR (2004) Alzheimer's disease abeta vaccine reduces central nervous system abeta levels in a non-human primate, the Caribbean vervet. Am J Pathol 165, 283-297.

[42] Britschgi M, Olin CE, Johns HT, Takeda-Uchimura Y, LeMieux MC, Rufibach K, Rajadas J, Zhang H, Tomooka B, Robinson WH, Clark CM, Fagan AM, Galasko DR, Holtzman DM, Jutel M, Kaye JA, Lemere CA, Leszek J, Li G, Peskind ER, Quinn JF, Yesavage JA, Ghiso JA, Wyss-Coray $T$ (2009) Neuroprotective natural antibodies to assemblies of amyloidogenic peptides decrease with normal aging and advancing Alzheimer's disease. Proc Natl Acad Sci U S A 106, 12145-12150.

[43] Wang J, Hara H, Makifuchi T, Tabira T (2008) Development and characterization of a TAPIR-like mouse monoclonal antibody to amyloid-beta. J Alzheimers Dis 14, 161-173.

[44] Winkler DT, Abramowski D, Danner S, Zurini M, Paganetti P, Tolnay M, Staufenbiel M (2010) Rapid cerebral amyloid binding by Abeta antibodies infused into beta-amyloid precursor protein transgenic mice. Biol Psychiatry 68, 971-974.

[45] Gessner JE, Heiken H, Tamm A, Schmidt RE (1998) The IgG Fc receptor family. Ann Hematol 76, 231-248.

[46] Wilcock DM, Rosenthal A, Ugen KE, Gordon MN, Morgan D (2004) Microglial activation facilitates A(beta) plaque removal following intracranial anti-A(beta) antibody administration. Neurobiol Dis 15, 11-20.

[47] Koenigsknecht-Talboo J, Meyer-Luehmann M, Parsadanian M, Garcia-Alloza M, Finn MB, Hyman BT, Bacskai BJ, Holtzman DM (2008) Rapid microglial response around amyloid pathology after systemic anti-Abeta antibody administration in PDAPP mice. J Neurosci 28, 14156-14164.

[48] Bard F, Barbour R, Cannon C, Carretto R, Fox M, Games D, Guido T, Hoenow K, Hu K, Johnson-Wood K, Khan K, Kholodenko D, Lee C, Lee M, Motter R, Nguyen M, Reed A, Schenk D, Tang P, Vasquez N, Seubert P, Yednock T (2003) Epitope and isotype specificities of antibodies to beta -amyloid peptide for protection against Alzheimer's disease-like neuropathology. Proc Natl Acad Sci U S A 100, 2023-2028.

[49] Bussiere T, Bard F, Barbour R, Grajeda H, Guido T, Khan K, Schenk D, Games D, Seubert P, Buttini M, (2004) Morphological characterization of thioflavin-s-positive amyloid plaques in transgenic Alzheimer mice and effect of passive A beta immunotherapy on their clearance. Am J Pathol 165, 987-995.

[50] Seubert P, Khan K, Motter R, Tang P, Kholodenko D, Kling K, Schenk D, Johnson-Wood K, Schroeter S, Gill D, Jacobsen JS, Pangalos M, Basi G, Games D (2008) Antibody capture of soluble Abeta does not reduce cortical Abeta amyloidosis in the PDAPP Mouse. Neurodegener Dis 5, 65-71.

[51] Banks WA, Farr SA, Morley JE, Wolf KM, Geylis V, Steinitz M (2007) Anti-amyloid beta protein antibody passage across the blood-brain barrier in the SAMP8 mouse model of Alzheimer's disease: An age-related selective uptake with reversal of learning impairment. Exp Neurol 206, 248-256.

[52] Siemers ER, Friedrich S, Dean RA, Gonzales CR, Farlow MR, Paul SM, Demattos RB (2010) Safety and changes in plasma and cerebrospinal fluid amyloid beta after a single administration of an amyloid beta monoclonal antibody in 
subjects with Alzheimer disease. Clin Neuropharmacol 33, 67-73.

[53] Levites Y, Smithson LA, Price RW, Dakin RS, Yuan B, Sierks MR, Kim J, McGowan E, Reed DK, Rosenberry TL, Das P, Golde TE (2006) Insights into the mechanisms of action of anti-Abeta antibodies in Alzheimer's disease mouse models. FASEB J 20, 2576-2578.

[54] Garg A, Joseph P, Balthasar JP (2009) Investigation of the influence of $\mathrm{FcRn}$ on the distribution of $\operatorname{IgG}$ to the brain AAPS J 11, 553-557.

[55] Solomon B, Koppel R, Frankel D, Hanan-Aharon E (1997) Disaggregation of Alzheimer beta-amyloid by site-directed mAb. Proc Natl Acad Sci U S A 94, 4109-4112.

[56] Bacskai BJ, McLellan ME, Games D, Seubert P, Schenk D, Hyman-Bradley T (2002) Non-Fc-mediated mechanisms are involved in clearance of amyloid-beta in vivo by immunotherapy. J Neurosci 22, 7873-7878.

[57] Das P, Loosbrock N, Dickson D, Murphy MP, Golde TE (2003) Amyloid-(beta) immunization effectively reduces amyloid deposition in Fcr(gamma)(-/-) knock-out mice. J Neurosci 23, 8532-8538.

[58] Wilcock-DM, Gottschall PE, Grimm J, Rosenthal A, Pons J, Ronan V, Symmonds K, Gordon MN, Morgan D (2006) Deglycosylated anti-amyloid-beta antibodies eliminate cognitive deficits and reduce parenchymal amyloid with minimal vascular consequences in aged amyloid precursor protein transgenic mice. J Neurosci 26, 1529-2401.

[59] Klyubin I, Betts V, Welzel AT, Blennow K, Zetterberg H, Wallin A, Lemere CA, Cullen WK, Peng Y, Wisniewski T, Selkoe DJ, Anwyl R, Walsh DM, Rowan MJ (2008) Amyloid beta protein dimer-containing human CSF disrupts synaptic plasticity: Prevention by systemic passive immunization. J Neurosci 28, 4231-4237.

[60] Racke MM, Hepburn DL, Parsadainian M, Bryan MT, Ness DK, Piroozi KS, Jordan WH, Brown DD, Hoffman WP, Holtzman DM, Bales KR, Gitter BD, May PC, Paul SM, DeMattos RB (2005) Exacerbation of cerebral amyloid angiopathyassociated microhemorrhage in amyloid precursor protein transgenic mice by immunotherapy is dependent on antibody recognition of deposited forms of amyloid beta. J Neurosci 25, 629-636.

[61] Weller RO, Boche D, Nicoll JA (2009) Microvasculature changes and cerebral amyloid angiopathy in Alzheimer's disease and their potential impact on therapy. Acta Neuropathol 118, $87-102$ 